\title{
The clinical diagnosis of Achilles tendinopathy: A scoping review
}

\author{
Wesley Matthews ${ }^{\text {Corresp., } 1}$, Richard Ellis ${ }^{2,3}$, James Furness ${ }^{1}$, Wayne A Hing ${ }^{1}$ \\ ${ }^{1}$ Bond Institute of Health and Sport, Faculty of Health Sciences and Medicine, Bond University, Gold Coast, Queensland, Australia \\ 2 Active Living and Rehabilitation: Aotearoa New Zealand, Health and Rehabilitation Research Institute, Faculty of Health and Environmental Sciences, \\ Auckland University of Technology, Auckland, New Zealand \\ 3 Department of Physiotherapy, School of Clinical Sciences, Faculty of Health and Environmental Sciences, Auckland University of Technology, Auckland, \\ New Zealand
}

Corresponding Author: Wesley Matthews

Email address: wesley.matthews@student.bond.edu.au

Background. Achilles tendinopathy describes the clinical presentation of pain localised to the Achilles tendon and associated loss of function with tendon loading activities. However, clinicians display differing approaches to the diagnosis of Achilles tendinopathy due to inconsistency in the clinical terminology, an evolving understanding of the pathophysiology, and the lack of consensus on clinical tests which could be considered the gold standard for diagnosing Achilles tendinopathy. The primary aim of this scoping review is to provide a method for clinically diagnosing Achilles tendinopathy that aligns with the nine core health domains. Methodology. A scoping review was conducted to synthesise available evidence on the clinical diagnosis and clinical outcome measures of Achilles tendinopathy. Extracted data included author, year of publication, participant characteristics, methods for diagnosing Achilles tendinopathy and outcome measures. Results. 159 articles were included in this scoping review. The most commonly used subjective measure was self-reported location of pain, while additional measures included pain with tendon loading activity, duration of symptoms, and tendon stiffness. The most commonly identified objective clinical test for Achilles tendinopathy was tendon palpation (including pain on palpation, localised tendon thickening or localised swelling). Further objective tests used to assess Achilles tendinopathy included tendon pain during loading activities (single-leg heel raises and hopping) and the Royal London Hospital Test and the Painful Arc Sign. The VISA-A questionnaire as the most commonly used outcome measure to monitor Achilles tendinopathy. However, psychological factors (PES, TKS and PCS) and overall quality of life (SF-12, SF-36 and EQ-5D-5L) were less frequently measured.

Conclusions. There is significant variation in the methodology and outcome measures used to diagnose Achilles tendinopathy. A method for diagnosing Achilles tendinopathy is proposed, that includes both results from the scoping review and recent recommendations 
for reporting results in tendinopathy. 


\section{The clinical diagnosis of Achilles Tendinopathy: A scoping review.}

2

3 Wesley Matthews ${ }^{1}$, Richard Ellis ${ }^{2,3}$, James Furness ${ }^{1}$, Wayne Hing ${ }^{1}$

4

$5{ }^{1}$ Bond Institute of Health and Sport, Faculty of Health Sciences and Medicine, Bond University, 6 Robina, Gold Coast, Queensland, Australia.

7

$8{ }^{2}$ Active Living and Rehabilitation: Aotearoa New Zealand, Health and Rehabilitation Research

9 Institute, Faculty of Health and Environmental Sciences, Auckland University of Technology. 10

$11{ }^{3}$ Department of Physiotherapy, School of Clinical Sciences, Faculty of Health and 12 Environmental Sciences, Auckland University of Technology

13

14 Corresponding Author:

15

16 Wesley Matthews ${ }^{1}$

17 Bond Institute of Health and Sport, Promethean Way, Robina, Queensland, 4226, Australia

18 Email address: wesley.matthews@student.bond.edu.au 
19

20

21

22

23

24

25

26

27

28

29

30

31

32

33

34

35

36

37

38

39

40

41

42

43

44

45

46

47

48

49

50

51

52

53

54

55

56

57

\section{Abstract}

Background. Achilles tendinopathy describes the clinical presentation of pain localised to the Achilles tendon and associated loss of function with tendon loading activities. However, clinicians display differing approaches to the diagnosis of Achilles tendinopathy due to inconsistency in the clinical terminology, an evolving understanding of the pathophysiology, and the lack of consensus on clinical tests which could be considered the gold standard for diagnosing Achilles tendinopathy. The primary aim of this scoping review is to provide a method for clinically diagnosing Achilles tendinopathy that aligns with the nine core health domains. Methodology. A scoping review was conducted to synthesise available evidence on the clinical diagnosis and clinical outcome measures of Achilles tendinopathy. Extracted data included author, year of publication, participant characteristics, methods for diagnosing Achilles tendinopathy and outcome measures.

Results. 159 articles were included in this scoping review. The most commonly used subjective measure was self-reported location of pain, while additional measures included pain with tendon loading activity, duration of symptoms, and tendon stiffness. The most commonly identified objective clinical test for Achilles tendinopathy was tendon palpation (including pain on palpation, localised tendon thickening or localised swelling). Further objective tests used to assess Achilles tendinopathy included tendon pain during loading activities (single-leg heel raises and hopping) and the Royal London Hospital Test and the Painful Arc Sign. The VISA-A questionnaire as the most commonly used outcome measure to monitor Achilles tendinopathy. However, psychological factors (PES, TKS and PCS) and overall quality of life (SF-12, SF-36 and EQ-5D-5L) were less frequently measured.

Conclusions. There is significant variation in the methodology and outcome measures used to diagnose Achilles tendinopathy. A method for diagnosing Achilles tendinopathy is proposed, that includes both results from the scoping review and recent recommendations for reporting results in tendinopathy.

\section{Introduction}

Achilles tendinopathy describes the clinical presentation of pain localised to the Achilles tendon and associated loss of function with tendon loading activities. ${ }^{1,2}$ However, clinicians display differing approaches to the diagnosis of Achilles tendinopathy due to inconsistency in the clinical terminology, an evolving understanding of the pathophysiology, and the lack of consensus on clinical tests which could be considered the gold standard for diagnosing Achilles tendinopthy. ${ }^{1-4}$ Conversely, when describing the clinical condition of persistent pain and dysfunction of the Achilles tendon in relation to mechanical loading, consensus agreement has identified the preferred terminology to be 'tendinopathy' rather than other common terms such as 'tendinitis' and 'tendinosis'. ${ }^{5}$ However, the consensus agreement for terminology does not provide a clear criteria with which to diagnose Achilles tendinopathy. ${ }^{1}$ 
58

59

60

61

62

63

64

65

66

67

68

69

70

71

72

73

74

75

76

77

78

79

80

81

82

83

84

85

86

87

88

89

90

91

92

93

94

95

96

97

98

Additionally, when considering the diagnosis of Achilles tendinopathy, distinctions can be made between the diagnosis of tendinopathy and clinical diagnosis of Achilles tendinopathy. As described by Aggarwal et al (2015), ${ }^{6}$ a diagnosis is based off a broad set of signs and symptoms to reflect all the potential features and severity of a pathology. Whereas, a clinical diagnosis of Achilles tendinopathy requires a specific set of signs, symptoms and tests to define a homogenous group of patients across studies and geographical regions. ${ }^{6}$ In the case of Achilles tendinopathy, the diagnosis of Achilles tendinopathy is determined by the presentation of pain localised to the Achilles tendon and associated loss of function with tendon loading activities. ${ }^{1,2}$ However, this broad description may include other pathological disease processes such as retrocalcaneal bursitis, complete or partial rupture of the Achilles, tarsal tunnel syndrome, neuroma/neuritis of the sural nerve, rupture posterior tibial tendon, or arthritic conditions of the ankle that need to be differentially diagnosed. ${ }^{7}$ Thus, it becomes relevant to understand the process to determine a clinical diagnosis of Achilles tendinopathy.

The clinical diagnosis of Achilles tendinopathy is predominantly derived from patient history, patient reported load related pain, and pain provocation tests. ${ }^{2}$ Patient history, localised Achilles tendon pain and pain on palpation are considered key to diagnosing Achilles tendinopathy ${ }^{1,2}$ and can all be assessed reliably. ${ }^{7}$ Additional pain provoking tests; such as the single leg heel raise, hop test, Royal London Hospital Test or Painful Arc Sign; have been suggested as useful to confirm a clinical diagnosis of Achilles tendinopathy. ${ }^{2,7,8}$ However, many leading researchers disagree on the which clinical tests are essential to diagnose Achilles tendinopathy. ${ }^{1}$ Conversely, it is agreed that uniform diagnostic criteria would be useful in identifying possible subclassifications of Achilles tendinopathy and thus improving tailored individual treatment programmes or monitoring patient progress. ${ }^{1}$

Recently, Vicenzino et al $(2020)^{9}$ identified nine core health domains in tendinopathy following consensus agreement from both health care practitioners and patients. These included patient rating of overall condition, pain on activity or loading, participation, function, psychological factors, disability, physical function capacity, quality of life, and pain over a specified timeframe. ${ }^{9}$ An overview of the nine core health domains of tendinopathy ${ }^{9}$ are presented in Table 1. Using the determined core health domains, specific measures will need to be identified specific to Achilles tendinopathy. ${ }^{9}$ The introduction of the nine core health domains in tendinopathy ${ }^{9}$ in addition to previously identified gaps in the literature, including; a lack of consistency in terminology used to diagnose Achilles tendinopathy, ${ }^{1,5}$ lack of a consensus on the clinical diagnosis of Achilles tendinopathy, ${ }^{1}$ and the need for a uniform method with which to clinically diagnose Achilles tendinopathy. ${ }^{1}$ Thus there is a requirement to identify the methods with which these gaps can be addressed and allow for greater consistency in the clinical diagnosis of Achilles tendinopathy in both research and clinical practice.

Therefore, the primary aim of this scoping review is to provide a method for clinically diagnosing Achilles tendinopathy that aligns with the nine core health domains. In order to 
102

103

104

105

106

107

108

109

110

111

112

113

114

115

116

117

118

119

120

121

122

123

124

125

126

127

128

129

130

131

132

133

134

135

136

137

138

achieve this, specific objectives have been determined that include; (1) identifying the most common clinical tests used to diagnose Achilles tendinopathy, (2) identifying the most common outcome measures used to assess Achilles tendinopathy, and (3) summarising the studies to date.

\section{Methodology}

\section{Study Design}

A scoping review was conducted to synthesise available evidence on the clinical diagnosis and clinical outcome measures of Achilles tendinopathy. Due to the wide-ranging nature of the topic, a scoping review was used to facilitate the collection and charting of evidence with the aim of identifying key themes, knowledge gaps and types of evidence currently available. Fig. 1 provides an overview of the overall study design and process to answer the primary aim and specific objectives.

\section{Search Strategy}

A single researcher (WM) completed a literature search to identify, screen and select studies in accordance with the Preferred Reporting Items for Systematic Reviews and MetaAnalysis Extension for Scoping Reviews (PRISMA-ScR). ${ }^{10}$ A detailed, multistep search of PubMed, CINAHL, ProQuest and SPORTDiscus was conducted between May 2020 and July 2020, before being updated in April 2021. In addition to the electronic database search, reference lists from included articles were reviewed for additional articles. To ensure a broad search, key words were truncated to allow for variations in spelling and combined using Boolean operators in addition to the use of MeSH terms to allow for review of all relevant articles. The full electronic search for the PubMed database is provided in Table 2.

\section{Eligibility Criteria}

Methods for data extraction specific to scoping reviews were informed by the PopulationConcept-Context framework as recommended by the Joanna Briggs Institute (JBI) Reviewer's Manual. ${ }^{11}$ Population was defined as any person clinically diagnosed with Achilles tendinopathy regardless of location (insertional or midportion). Concept included any study reporting on the methods used to clinically diagnose Achilles tendinopathy including subjective measures, objective measures and outcome measures. Context included all periods of time, outcomes, comparators, follow-up, rehabilitation settings, and duration and type of intervention.

Eligible articles were full-text and included original research, reviews, scoping reviews, systematic reviews, meta-analyses, case-series and clinical commentaries. Studies were included if they provided adequate information on the method of clinical diagnosis (either subjective measures, objective measures or both subjective and objective measures), and clinical outcome measures used. Studies were excluded if they were non-English, had no description of clinical diagnosis, not specific to Achilles tendinopathy or included asymptomatic Achilles tendon states only. 
139

140

141

142

143

144

145

146

147

148

149

150

151

152

153

154

155

156

157

158

159

160

161

162

163

164

165

166

167

168

169

170

171

172

173

174

175

176

177

178

\section{Data Extraction and Synthesis}

WM extracted data from publications meeting the inclusion criteria into an Excel spreadsheet. Data extraction, grouping and plotting were performed by WM in line with previously published recommendations, ${ }^{11}$ where extracted data included author, year of publication, participant characteristics, methods for diagnosing Achilles tendinopathy and outcome measures. Data was extracted in tabular and graphical forms with results grouped by study design and categorised according to the hierarchy of evidence. ${ }^{12-14}$ Diagnostic criteria were presented in tabular form including year of publication, population, subjective and objective measures. Terminology and outcome measures were presented in graphical form with terminology grouped by publication year and outcome measures grouped by purpose of measure (disability, pain, psychological, quality of life).

Following data extraction, data synthesis was performed according to a previously published methodological framework. ${ }^{15}$ Data was synthesised into the following categories: 1) subjective measures, 2) objective measures and 3) outcome measures. Results were plotted according to publication date, terminology, study design and clinical diagnostic measures. Results were then compared to the nine core health domains of tendinopathy ${ }^{9}$ to identify areas of overlap and gaps in the current evidence. Studies could be allocated to multiple groups. Quality appraisal was not required as per recommended methodology for scoping reviews. ${ }^{11,16}$

\section{Results}

\section{Selection of sources of evidence}

The search results are displayed in the PRISMA Flow Diagram (Fig. 2). The search strategy generated 11561 results with two further results identified via reference list searching. Following duplicate removal and title and abstract screening, 554 full-text articles were reviewed for inclusion in the study. Of these, 395 were excluded for the following reasons: 240 provided insufficient information on the method of diagnosing Achilles tendinopathy, 11 assessed asymptomatic Achilles tendons only, 46 did not have access to the full text, 52 were not in English and 47 were not specific to Achilles tendinopathy. Thus, 159 articles ${ }^{2,7,8,17-172}$ were included in this scoping review.

\section{Characteristics of sources of evidence}

In grouping the included articles by publication type, narrative reviews were the most common $(27.2 \%)$ followed by cohort studies (19.6\%), case control studies $(18.8 \%)$, randomised controlled trials $(12.7 \%)$, cross-sectional studies $(10.8 \%)$, case reports $(3.8 \%)$, protocols $(3.2 \%)$, systematic reviews (1.9\%), clinical guidelines (1.9\%) and one consensus statement $(0.6 \%)$. The years of publication of included studies ranged from 1980 to 2020, with 2017 to 2020 producing the most publications. Table 3 provides the general characteristics of the reviewed studies, including year of publication, type of publication, terminology and tendinopathy location. 
179

180

181

182

183

184

185

186

187

188

189

190

191

192

193

194

195

196

197

198

199

200

201

202

203

204

205

206

207

208

209

210

211

212

213

214

215

216

217

218
As highlighted in Fig. 3, the terminology used to describe tendon pain varied, with 'tendinopathy' being the most prevalent term used to describe tendon pain. Thus, during this scoping review, tendinopathy, will be used to describe pain located in the Achilles tendon that impairs function.

\section{Results of individual sources of evidence \\ Clinical Guidelines and Consensus Statements}

Two of the included clinical guidelines 37,108 discussed midportion Achilles tendinopathy, with one clinical guideline ${ }^{156}$ and one consensus statement ${ }^{167}$ discussing insertional Achilles tendinopathy (Table 4). Clinical measures used to diagnose Achilles tendinopathy was consistent across the clinical guidelines and consensus statement, with location of pain being the main differentiating factor between diagnosing midportion or insertional tendinopathy. Common methods with which midportion tendinopathy was diagnosed included subjective reporting of pain located in the Achilles tendon 2-6cm above the calcaneal insertion that is increased with tendon loading and reported tendon stiffness. Similarly, insertional tendinopathy was diagnosed via subjective reporting of pain and swelling at the calcaneal insertion of the Achilles tendon. Pain on palpation was utilised to confirm clinical diagnosis in both midportion and insertional tendinopathy. While additional objective tests for midportion tendinopathy included the 'Painful Arc Sign' and 'Royal London Hospital Test'.

\section{Systematic Reviews}

All three included systematic reviews assessed midportion Achilles tendinopathy (Table 5). ${ }^{8,71,104}$ Subjective reporting of pain with tendon loading was included as a diagnostic feature of midportion Achilles tendinopathy in all three systematic reviews. ${ }^{8,71,104}$ Two of the systematic reviews ${ }^{8,71}$ identified the location of tendon pain as $2-6 \mathrm{~cm}$ above the calcaneal insertion, with one $^{104}$ defining the location of tendon pain as $2-7 \mathrm{~cm}$ above the calcaneal insertion. Palpation of the Achilles tendon, passive dorsiflexion, pain with single-leg heel raise and pain hopping or jumping were included as clinical tests in all included systematic reviews. ${ }^{8,71,104}$ Two of the systematic reviews ${ }^{8,71}$ included the 'Painful Arc Sign' and 'Royal London Hospital Test' as diagnostic measures for midportion Achilles tendinopathy.

\section{Randomised Controlled Trials}

Table 6 highlights the characteristics of the included randomised controlled trials. Thirteen of the included studies ${ }^{34,36,85,103,109,123,126,135,137,138,150,153,159}$ investigated midportion Achilles tendinopathy, one study ${ }^{136}$ investigated insertional Achilles tendinopathy, two studies ${ }^{64,82}$ investigated both insertional and midportion Achilles tendinopathy, and four studies $^{33,56,131,148}$ did not specify a location of interest. All of the included randomised controlled trials used location of pain as a diagnostic feature of Achilles tendinopathy. Eight of the studies $^{82,103,123,126,135,136,138,153}$ which assessed midportion tendinopathy defined the location of

Peer] reviewing PDF | (2021:05:60805:1:0:NEW 12 Aug 2021) 
219 pain as $2-6 \mathrm{~cm}$ above the calcaneal insertion, with three studies ${ }^{34,85,159}$ defining midportion 220 tendinopathy as $2-7 \mathrm{~cm}$ above the calcaneal insertion. Of the included studies, 17 included 221 symptom duration as part of their diagnostic criteria, with various durations including four 222 weeks, ${ }^{138}$ six weeks, ${ }^{36}$ two months, ${ }^{64,159}$ three months, ${ }^{34,56,103,123,126,131,148,150}$ and six months. ${ }^{109,135-}$

223 137,153 Palpation was the most commonly used objective test, with 15 of the included

224 studies $^{33,34,36,64,85,103,109,123,126,131,136,138,148,153,159}$ using palpation to assess pain, localised tendon 225 thickening or localised swelling. Four studies ${ }^{56,82,135,137}$ used solely subjective history to diagnose 226 Achilles tendinopathy.

227

228

229

230

231

232

233

234

235

236

237

238

239

240

241

242

243

\section{Cohort Studies}

Of the included cohort studies, 21 were prospective cohort studies, ${ }^{40,41,49,55,76,79-}$ $81,83,102,105,110,117,118,121,122,142,147,154,171$ and 10 were retrospective cohort studies. ${ }^{22,27,60,112,152,163,165,166,168,170}$ Midportion Achilles tendinopathy was investigated in 15

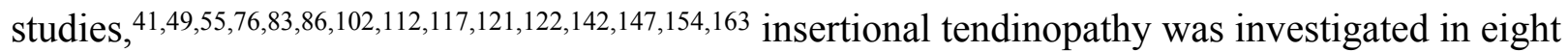
studies, ${ }^{40,105,110,152,165,168,170,171}$ both insertional and midportion tendinopathy was investigated in five studies, ${ }^{22,79-81,166}$ and three studies did not specify tendinopathy location (Table 7). ${ }^{27,60,118}$

Location of pain was the most prominent diagnostic feature, with 26

studies $40,41,49,55,60,76,79,81,83,86,102,105,110,112,117,118,142,147,152,154,163,165,166,168,170,171$ using it as a criteria to diagnose both midportion and insertional Achilles tendinopathy. Midportion tendinopathy was defined as an area $2-4 \mathrm{~cm}$ above the calcaneal insertion in two studies, ${ }^{49,166} 2-6 \mathrm{~cm}$ above the calcaneal insertion in six studies, ${ }^{41,81,83,102,142,154}$ and $2-7 \mathrm{~cm}$ above the calcaneal insertion in one study. ${ }^{112}$ Insertional tendinopathy was defined as the distal $2 \mathrm{~cm}$ in three studies, ${ }^{40,106,110}$ and the

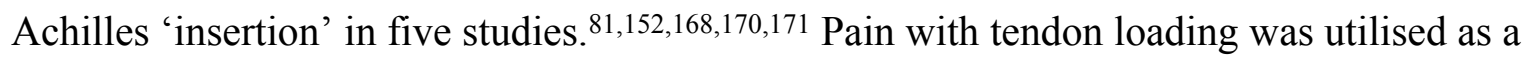
diagnostic criteria in 18 studies, $22,27,40,60,80,81,102,110,112,117,121,122,142,147,154,163,165,166$ and duration of

244 symptoms was utilised in 16 studies. ${ }^{40,41,55,76,79,83,86,110,117,118,122,147,152,163,165,170}$ Duration of

245 symptoms varied significantly with studies defining tendinopathy as symptoms lasting less than

246 six months, ${ }^{122}$ more than six weeks, ${ }^{110,163}$ more than two months, ${ }^{147}$ more than three 247 months, ${ }^{41,83,117,152,170}$ more than six months, ${ }^{40,76,86,118,165}$ and more than one year. ${ }^{55}$ As with the 248 previous studies, the most common objective test for diagnosing Achilles tendinopathy was 249 palpation, with 23 studies utilising it as a diagnostic

250 criteria. ${ }^{27,41,49,55,60,76,79,80,83,102,105,110,112,117,121,122,142,154,163,165,166,168,171}$ Six studies used only

251 subjective measures for diagnosing Achilles tendinopathy. ${ }^{22,40,81,86,118,170}$

252

253

Case-control Studies

254

255

Of the 30 case-control studies, one ${ }^{42}$ investigated insertional Achilles tendinopathy, 15

256 studies $7,17,25,48,63,88,94,113,114,127,132,134,139,145,172$ investigated midportion Achilles tendinopathy, nine studies $44,46,57,67,119,130,133,162,169$ investigated both insertional and midportion Achilles tendinopathy, with five studies ${ }^{38,68,75,87,116}$ not specifying tendinopathy location (Table 8 ). As with the previous study types, the most commonly used diagnostic feature was location of pain, which was utilised in 27 of the case-control 
260

261

262

263

264

265

266

267

268

269

270

271

272

273

274

275

276

277

278

279

280

281

282

283

284

285

286

287

288

289

290

291

292

293

294

295

296

297

298

299

studies. $7,17,42,44,46,48,57,63,67,68,75,87,88,113,114,116,119,127,130,132-134,139,145,162,169,172$ Insertional tendinopathy was defined as the distal $2 \mathrm{~cm}$ of the Achilles tendon in three studies. ${ }^{44,130,162}$ Midportion tendinopathy was defined as $2-6 \mathrm{~cm}$ above the calcaneal insertion in eight studies, ${ }^{7,44,114,130,132,139,162,169} 2-7 \mathrm{~cm}$ above the calcaneal insertion in three studies, ${ }^{63,88,145}$ and the middle third of the tendon in one study. ${ }^{113}$ Additionally, duration of symptoms was commonly used to diagnose Achilles tendinopathy, with variations in the criteria. Achilles tendinopathy was defined as duration of symptoms of less than three months in one study, ${ }^{114}$ greater than four weeks in two studies, ${ }^{75,113}$ greater than two months in one study, ${ }^{116}$ greater than three months in eight studies, ${ }^{44,46,57,119,134,139,162,172}$ and greater than six months in three studies. ${ }^{63,87,127}$ Pain with tendon loading was included as a diagnostic criteria in 18 studies. $17,25,38,42,44,48,57,67,68,75,88,132$ $134,139,145,162,172$ One study did not specify a subjective criteria to diagnose Achilles tendinopathy. ${ }^{94}$ Similar to previous study designs, palpation was the most common clinical test to diagnose Achilles tendinopathy, with it being used in 26 studies. .,17,25,38,42,44,46,48,57,63,68,87,88,94,113,114,116,119,127,132-134,145,162,169,172 Four studies relied only on subjective measures to diagnose Achilles tendinopathy. ${ }^{67,75,130,139}$

\section{Cross-sectional Studies}

Table 9 provides an overview of the 17 included cross-sectional studies, with 10 studies $^{50,51,53,59,98,129,141,143,160,164}$ investigating midportion Achilles tendinopathy, four studies ${ }^{54,84,157,158}$ investigating both insertional and midportion Achilles tendinopathy, and three studies ${ }^{18,89,107}$ not specifying tendinopathy location. Once again, location of pain was the most common subjective measure to diagnose Achilles tendinopathy, with 12 studies utilising it as a diagnostic criteria. ${ }^{50,51,84,98,107,129,141,143,157,158,160,164}$ Midportion Achilles tendinopathy was defined as $2-6 \mathrm{~cm}$ above the calcaneal insertion in four studies, ${ }^{51,98,129,164}$ and $2-7 \mathrm{~cm}$ above the calcaneal insertion in one study. ${ }^{160}$ Similarly, 12 studies included duration of symptoms as a diagnostic criteria, with durations of symptoms including greater than four weeks, ${ }^{141}$ greater than two months, ${ }^{129,160}$ greater than three months, ${ }^{59,98,107,143,157,158,164}$ greater than four months, ${ }^{84}$ and greater than six months. ${ }^{51}$ Pain with tendon loading was the next most common subjective diagnostic measure, with nine studies including it as a diagnostic measure. ${ }^{51,54,59,98,143,157,158,160,164}$ One study ${ }^{53}$ did not report subjective measures to confirm the diagnosis of Achilles tendinopathy. The most common clinical test included palpation, with nine studies using palpation to clinically diagnose Achilles tendinopathy. ${ }^{53,59,84,89,98,107,129,160,164}$ Four studies $^{18,89,141,164}$ included the Royal London Hospital Test as a clinical measure of Achilles tendinopathy, with four studies ${ }^{50,51,143,157}$ not specifying the clinical tests utilised to confirm the diagnosis.

\section{Narrative Reviews}

Of the 43 narrative reviews included in the scoping review, seven studies investigated insertional Achilles tendinopathy, ${ }^{19,30,43,52,70,72,99} 18$ studies investigated midportion Achilles tendinopathy, ${ }^{20,21,26,47,58,73,78,90,93,97,100,101,111,120,144,146,149,155} 13$ studies investigated both insertional 
300

301

302

303

304

305

306

307

308

309

310

311

312

313

314

315

316

317

318

319

320

321

322

323

324

325

326

327

328

329

330

331

332

333

334

335

336

337

338

339

and midportion Achilles tendinopathy, ${ }^{23,24,32,39,45,61,62,69,77,91,96,125,140}$ and four studies did not specify tendinopathy location (Table 10).2,29,92,115,151 The most common subjective diagnostic criteria for diagnosing Achilles tendinopathy was pain with tendon loading, with all 43 included reviews utilising as a diagnostic criteria. ${ }^{2}, 19-21,23,24,26,29,30,32,39,43,45,47,52,58,61,62,69,70,72,73,77,78,90-$

93,96,97,99-101,111,115,120,125, 140,144,146,149,151,155 Location of pain was included as a diagnostic criteria of Achilles tendinopathy in 31 studies, with midportion tendinopathy defined as 'midportion' in two studies, ${ }^{140,155}$ distal $5 \mathrm{~cm}$ of the Achilles tendon in one study, ${ }^{115} 2-5 \mathrm{~cm}$ above the calcaneal insertion in three studies, ${ }^{26,62,149} 2-6 \mathrm{~cm}$ above the calcaneal insertion in 13 studies, ${ }^{20,24,58,61,69,78,90,91,93,100,101,125,146}$ and 4-6cm above the calcaneal insertion in one study. ${ }^{97}$ The third most common subjective criteria reported was tendon stiffness, with 24 studies including it as a diagnostic criteria. ${ }^{2}, 20,21,24,26,29,30,39,43,45,47,58,61,70,72,77,78,92,96,99,111,115,125,155$ As with previous study types, the most common clinical test used to diagnose Achilles tendinopathy was palpation, with all 43 included reviews including it as a clinical measure. ${ }^{2,19-}$

$21,23,24,26,29,30,32,39,433,45,47,52,58,61,62,69,70,72,73,77,78,90-93,96,97,99-101,111,115,120,125,140,144,146,149,151,155$ There was then significant variation in other clinical tests used to diagnose Achilles tendinopathy, with nine studies including the Painful Arc Sign, 2,23,58,69,78,90,92,93,96 seven studies including reduced range of motion, ${ }^{32,39,43,62,70,97,115}$ six studies including the Royal London Hospital Test, $, 58,69,77,90,96$ and six studies including pain whilst hopping as a clinical diagnostic criteria. ${ }^{2,21,26,45,58,115}$

\section{Case-reports}

Table 11 highlights the characteristics of the included case report studies. Five studies $^{35,74,95,124,161}$ investigated midportion Achilles tendinopathy and one study ${ }^{31}$ investigated insertional Achilles tendinopathy. As with the narrative reviews, the most common subjective measure used to diagnose Achilles tendinopathy was pain with tendon loading, ${ }^{31,35,74,95,124}$ with the second most common diagnostic criteria being location of pain. ${ }^{31,74,95,161}$ Midportion Achilles tendinopathy was defined as a location of pain $2-4 \mathrm{~cm}$ above the calcaneal insertion in one study, ${ }^{95}$ and $4-7 \mathrm{~cm}$ above the calcaneal insertion in another study. ${ }^{161}$ Five studies $35,74,95,124,161$ used palpation as an objective measure for diagnosing Achilles tendinopathy, with three studies ${ }^{35,74,124}$ utilising the pain during single-leg heel raise and one study ${ }^{31}$ not specifying any objective clinical tests.

\section{Protocols}

Of the five included protocol studies, two studies ${ }^{65,66}$ investigated midportion Achilles tendinopathy, one study ${ }^{106}$ investigated insertional Achilles tendinopathy and two studies ${ }^{28,128}$ investigated both insertional and midportion Achilles tendinopathy (Table 12). The most common reported subjective criteria utlised to diagnose Achilles tendinopathy was location of pain, with midportion Achilles tendinopathy defined as pain 2-6cm above the calcaneal insertion in two studies, ${ }^{28,66}$ and $2-7 \mathrm{~cm}$ above the calcaneal insertion in one study. ${ }^{65}$ Insertional tendinopathy was defined as the distal $2 \mathrm{~cm}$ of the Achilles tendon in one study ${ }^{106}$ and the Achilles 'insertion' in another study. ${ }^{28}$ Clinical diagnostic tests varied with three studies $28,65,106$ 
340 including palpation, two studies ${ }^{28,128}$ including pain during a single-leg heel raise and two studies including pain during hopping. ${ }^{6,117}$ One study did not specify objective clinical tests. ${ }^{66}$

342

343

\section{Outcome Measures}

344

Within the 159 included articles there were 42 different outcome measures in the clinical diagnosis of Achilles tendinopathy, with 49 studies $2,8,19,21,23,27,29,30,32,33,38,39,43,47,50,52,54,60-$ $62,68,69,72,73,77,78,83,91,93-97,100,101,111,115,120,121,125,139,140,146,149,151,156,166,167,169$ not reporting any outcome measures. Of the 110 included studies to report on outcome measures $7,17,18,20,22,24-26,28,31,34-37,40-$ $42,44-46,48,49,51,53,55-59,63-67,70,71,74-76,79-82,84-90,92,98,99,102-110,112-114,116-119,122-124,126-138,141-145,147,148,150,152-$ 155,157-165,168,170-172, 42 different outcome measures were utilised. Disability was the most

350 commonly measured outcome, with 28 different outcome measures for disability being applied 135 times (Fig. 4). The most common outcome measure for disability was the VISA-A questionnaire, being used in $75 \%$ of the studies reporting outcome meaures. ${ }^{17,18,22,24,26,28,31,34,36,37,40,42,44-46,48,53,56-59,63-67,71,74-76,80,84-90,92,98,99,102,104-108,110,113,116-~}$ 119,127,129,130,132-137,141-145,147,150,154,155,157-161,163-165,168,170,172 Following, disability, the second most common outcome measure was pain with the $\operatorname{VAS}^{7,20,22,28,34,41,56,65,71,81,82,99,103-}$ $106,126,131,132,134,141,144,148,152,153,157,159,161,162,165,170-172$ being used in 30\% of studies reporting outcome measures and numerical pain rating scale (NPRS) $35,36,42,44,46,66,74,85,107,117,123,124,128,135-$ $137,154,158$ being used in $17 \%$ of studies reporting outcome measures. Outcome measures related to quality of life were utilised within 12 studies, with the most common outcome measures used being the 12-Item Short Form Survey (SF-12), 55,65,106,112,152 EuroQol 5 Dimension 5 Level Questionnaire (EQ-5D-5L) ${ }^{41,51,65,66}$ and 36-Item Short Form Survey (SF-36). ${ }^{71,99,126}$ Similarly, psychosocial outcomes were poorly measured, being utilised on 11 occasions, with the most common outcome measures being the Pain Catastrophizing Scale (PCS), ${ }^{44,57,66,128,158}$ Tampa Kinesiophobia Scale (TKS), ${ }^{44,66,128,158}$ Pain Disability Index (PDI) ${ }^{109,144}$ and Pain Efficacy Scale (PES). ${ }^{109,144}$

\section{Discussion}

\section{Overview}

The clinical diagnosis of tendinopathy is commonly determined via both patient history and clinical tests. ${ }^{4,173-178}$ However, with no consensus on gold standard clinical tests with which to diagnose tendinopathy, ${ }^{3}$ many research studies utilise a variety of measures to diagnose Achilles tendinopathy. ${ }^{7}$ The primary aim of this scoping review was to provide a method for clinically diagnosing Achilles tendinopathy that aligns with the nine core health domains. In order to achieve this, specific objectives were determined that included identifying the most common clinical tests used to diagnose Achilles tendinopathy, identifying the most common outcome measures used to assess Achilles tendinopathy, and summarising the studies to date. This will allow for greater consistency in both research and clinical settings. Additionally, this review aimed to identify the both the areas of strength and weakness 
380

381

382

383

384

385

386

387

388

389

390

391

392

393

394

395

396

397

398

399

400

401

402

403

404

405

406

407

408

409

410

411

412

413

414

415

416

417

418

419

\section{Terminology}

As highlighted in Fig. 3, 'Tendinopathy' was the most commonly term used to describe persistent Achilles tendon pain, particularly in more recent studies. This scoping review aligns with the previous consensus statements advocating the consistent use of the term tendinopathy to describe persistent Achilles tendon pain and associated loss of function in relation to mechanical loading. ${ }^{5}$ There was a noticeable reduction of the use of alternative terms such as tendinitis and tendinosis, particularly since 2018 , indicating progression towards unifying the terminology used to describe the clinical condition of persistent pain and dysfunction in the Achilles tendon that is associated with mechanical loading.

A difficulty identified in this scoping review was the inclusion of symptom duration as a measure to diagnose Achilles tendinopathy (Tables 6, 7, 8 and 9). When used as a measure, duration of symptoms varied significantly from four weeks up to 12 months, making identifying a consistent duration of symptoms to diagnose Achilles tendinopathy difficult and potentially contributing to the different terminology used within research and clinical practice. The term tendinitis indicates an inflammatory condition of the Achilles tendon that may develop symptoms in a shorter duration of time, whereas tendinosis indicates a change in tendon structure that would require a longer duration of time for symptoms to develop. ${ }^{5}$ Additionally, the clinical condition of Achilles tendinopathy does not display the characteristics of an inflammatory response such as with tissue tearing, ${ }^{4}$ and the structural changes, as those expected in tendinosis, are not required to be present for pain or dysfunction to develop. ${ }^{4}$

\section{The nine core health domains of tendinopathy}

Vicenzino et al $(2020)^{9}$ reported that the lack of agreed upon tendon health related domains impedes the progress of tendinopathy research. The nine identified domains (patient rating of overall condition, pain on activity or loading, participation, function, psychological factors, disability, physical function capacity, quality of life, and pain over a specified timeframe) should allow for greater consistency in the reporting of tendon research. ${ }^{9}$ This scoping review further highlights the inconsistency in the methods used to diagnose and assess Achilles tendinopathy. There was variation in the methodology used to clinically diagnose and assess Achilles tendinopathy for all key themes; subjective history, clinical tests and outcome measures.

\section{Subjective history}

Multiple measures were identified to determine a diagnosis of Achilles tendinopathy from the subjective interview (Tables 4, 5, 6, 7, 8, 9, 10, 11 and 12). The most commonly used measure was self-reported location of pain, with midportion Achilles tendinopathy most commonly being defined as an area located 2-6cm above the calcaneal insertion of the Achilles tendon. Insertional tendinopathy was most commonly defined as the distal $2 \mathrm{~cm}$ of the Achilles tendon. Additional measures included pain with tendon loading activity, duration of symptoms, 
420

421

422

423

424

425

426

427

428

429

430

431

432

433

434

435

436

437

438

439

440

441

442

443

444

445

446

447

448

449

450

451

452

453

454

455

456

457

458

and tendon stiffness following tendon loading or at a particular time of the day (i.e. morning stiffness). Interestingly, while a change in Achilles tendon loading activity (both an increase and decrease) is considered a catalyst for Achilles tendinopathy, ${ }^{4}$ it was only utilised in as a specific criterion in nine of the included studies. ${ }^{26,28,45,47,58,97,115,149,151}$

\section{Objective clinical tests}

As with subjective history, numerous clinical tests were identified to diagnose Achilles tendinopathy (Tables 4, 5, 6, 7, 8, 9, 10, 11 and 12). The most commonly identified clinical test for Achilles tendinopathy was tendon palpation (including pain on palpation, localised tendon thickening or localised swelling). Although, palpation is commonly used to identify the region of pain and is a common clinical measure use to diagnose Achilles tendinopathy, ${ }^{7,8,94,108}$ studies reported multiple regions of interest for midportion Achilles tendinopathy. Painful regions were described as the 'midportion', 'middle third', 2 to $4 \mathrm{~cm}, 2$ to $5 \mathrm{~cm}, 2$ to $6 \mathrm{~cm}, 2$ to $7 \mathrm{~cm}, 4$ to $6 \mathrm{~cm}$, and 4 to $7 \mathrm{~cm}$ above the calcaneal insertion. Similarly, the region of interest in insertional Achilles tendinopathy was described as the 'insertion', calcaneal tuberosity, distal $2 \mathrm{~cm}$, and distal $5 \mathrm{~cm}$.

While there was consistency in the included studies in their use of palpation as a clinical test, there is significant variation in the additional clinical tests used to confirm a diagnosis of Achilles tendinopathy (Tables 4, 5, 6, 7, 8, 9, 10, 11 and 12). Further clinical tests used to assess Achilles tendinopathy included tendon pain during loading activities (single-leg heel raises and hopping). The most frequently used clinical, tendinopathy specific tests, were the Royal London Hospital Test and the Painful Arc Sign. The Royal London Hospital Test is considered positive when the is a reduction in palpable Achilles tendon pain on ankle dorsiflexion. ${ }^{94}$ The Painful Arc Sign is considered positive when the area of swelling identified with palpation moves with active ankle plantarflexion and dorsiflexion. ${ }^{94}$

\section{Outcome measures}

As was the case for the clinical features, there were significant variations in the outcome measures utilised for making a diagnosis of Achilles tendinopathy (Fig. 4). While overall disability and participant perceived pain were commonly measured, the impact of Achilles tendinopathy on quality of life and psychological factors were rarely measured. Psychological factors such as pain efficacy, catastrophisation and kinesiophobia scales were identified as important outcome measures in the diagnosis tendinopathy, ${ }^{9}$ which aligns with the identified psychological outcome measures (PES, TKS and PCS). Similarly, disability measures that combine patient rated pain and function in relation to tendon-specific activities were identified as integral to monitoring tendinopathy outcomes. This scoping review identified the VISA-A questionnaire as the most commonly used outcome measure to monitor Achilles tendinopathy. In addition to psychological factors and disability, overall quality of life was identified as a core 
459 health domain in tendinopathy. ${ }^{9}$ The scoping review identified three different outcome measures

460 (SF-12, SF-36 and EQ-5D-5L) that were utilised to assess participant quality of life.

461

462

463

464

465

466

467

468

469

470

471

472

473

474

475

476

477

478

479

480

481

482

483

484

485

486

487

488

489

490

491

492

493

494

495

496

497

498

\section{An example evidence-based method for clinically diagnosing Achilles tendinopathy.}

While there was significant variation in the methods used to diagnose Achilles tendinopathy, some common themes can be identified. When considering a consistent method for diagnosing and assessing Achilles tendinopathy, it is important to ensure research follows consensus recommendations on both terminology used and reporting outcomes. ${ }^{5,9}$ Thus, Table 13 provides an amalgamation of the common features used to diagnose Achilles tendinopathy identified in the scoping review and the previously identified nine core health domains for tendinopathy. ${ }^{9}$ While the VISA-A is Achilles tendon specific, any validated and reliable pain questionnaire and quality of life questionnaire may be used in place of the Pain Catastrophising Scale and SF-12.

\section{Limitations}

This review was limited to publications in English, which may have excluded key studies published in other languages. Additionally, the screening, inclusion, exclusion, and data extraction was performed by one reviewer (WM), which decrease the probability all relevant studies were identified for review and could lead to reviewer bias. The methodological quality of the studies was not assessed as per guidelines for completing scoping reviews, ${ }^{11,16}$ meaning studies of poor design are given equal weighting to those of better quality, however, the descriptive nature of the scoping review limits the potential impact of individual studies' methodological quality on results. The aim of a scoping review is to provide an overview of all literature within a field of evidence, ${ }^{179}$ and while there is no specific requirement for methodological quality appraisal, assessing individual literature methodological quality utilising a standardised tool may help authors identify gaps in the literature related to low quality research in addition to lack of research.

\section{Conclusions}

The specific objectives, including the most common clinical tests used to diagnose Achilles tendinopathy and identifying the most common outcome measures used to assess Achilles tendinopathy were highlighted, with the scoping review identifying the significant variation in the methodology and outcome measures used to diagnose Achilles tendinopathy. This scoping review provides a detailed summary of the current evidence and common themes were identified in the available research to provide and evidence-based method to diagnose Achilles tendinopathy utilising both subjective and objective testing, in addition to recommendations regarding common outcome measures. The primary aim of this scoping review was to identify and provide a method for clinically diagnosing Achilles tendinopathy that aligns with the nine core health domains and a method for diagnosing Achilles tendinopathy is

Peer) reviewing PDF | (2021:05:60805:1:0:NEW 12 Aug 2021) 
499 proposed, that includes both results from the scoping review and recent recommendations for 500 reporting results in tendinopathy. The development of a method for the clinical diagnosis of

501 Achilles tendinopathy is key to developing greater homogeneity in future research. By

502 standardising the clinical diagnosis of Achilles tendinopathy, future research is able to

503 investigate other areas of this complex condition and identifying possible subclassifications of

504 Achilles tendinopathy and thus improving tailored individual treatment programmes or

505 monitoring patient progress. Additionally, an evidence-based method for the clinical diagnosis of

506 Achilles tendinopathy will allow clinicians to be more confident with their diagnosis and provide

507 patients with greater certainty.

508

509

\section{References}

510

511 1. de Vos R-J, van der Vlist AC, Winters M, van der Giesen F, Weir A. Diagnosing Achilles

512

513

514 tendinopathy is like delicious spaghetti carbonara: it is all about key ingredients, but not all chefs

515

516

517

518

519

520

521

522

523

524

525

526 use the same recipe. Br J Sports Med. 2021;55(5):247-248. doi:10.1136/bjsports-2020-102863.

2. Millar NL, Silbernagel KG, Thorborg K, et al. Tendinopathy (primer). Nat Rev Dis Primers. 2021;7(1) doi:10.1038/s41572-020-00234-1.

3. Docking SI, Ooi CC, Connell D. Tendinopathy: is imaging telling us the entire story? J Orthop Sports Phys Ther. 2015;45(11):842-852. doi:10.2519/jospt.2015.5880.

4. Cook JL, Rio E, Purdam CR, Docking SI. Revisiting the continuum model of tendon pathology: what is its merit in clinical practice and research? Br J Sports Med. 2016;50(19):1187-1191. doi:10.1136/bjsports-2015-095422.

5. Scott A, Squier K, Alfredson H, et al. ICON 2019: International Scientific Tendinopathy Symposium consensus: clinical terminology. Br J Sports Med. 2020;54(5):260. doi:10.1136/bjsports-2019-100885.

6. Aggarwal R, Ringold S, Khanna D, et al. Distinctions Between Diagnostic and Classification Criteria? Arthritis Care Res (Hoboken). 2015;67(7):891-897. doi:10.1002/acr.22583.

7. Hutchison AM, Evans R, Bodger O, et al. What is the best clinical test for achilles tendinopathy?

527

528

529

530

531

532

533

534 Foot Ankle Surg. 2013;19(2):112-117. doi:10.1016/j.fas.2012.12.006.

8. Reiman M, Burgi C, Strube E, et al. The utility of clinical measures for the diagnosis of Achilles tendon injuries: a systematic review with meta-analysis. J Athl Train. 2014;49(6):820-829. doi:10.4085/1062-6050-49.3.36.

9. Vicenzino B, de Vos R-J, Alfredson H, et al. ICON 2019-International Scientific Tendinopathy Symposium consensus: there are nine core health-related domains for tendinopathy (CORE DOMAINS): delphi study of healthcare professionals and patients. Br J Sports Med. 2020;54(8):444-451. doi:10.1136/bjsports-2019-100894.

535 10. Tricco AC, Lillie E, Zarin W, et al. PRISMA Extension for Scoping Reviews (PRISMA-ScR) :

536

537

538

539 Checklist and Explanation. Ann Intern Med. 2018;169(7):467-473. doi:10.7326/M18-0850.

11. Peters M, Godfrey C, McInerney P, Munn Z, Tricco AC, Khalil H. Chapter 11: Scoping Reviews (2020 Version). In: Aromataris E, Munn Z, eds. JBI Manual for Evidence Synthesis: JBI; 2020.

540

12. Daly J, Willis K, Small R, et al. A hierarchy of evidence for assessing qualitative health research. J Clin Epidemiol. 2006;60(1):43-49. doi:10.1016/j.jclinepi.2006.03.014. 
541 13. Evans D. Hierarchy of evidence: a framework for ranking evidence evaluating healthcare

542

543

544

545

546

547

548

549

550

551

552

553

554

555

556

557

558

559

560

561

562

563

564

565

566

567

568

569

570

571

572

573

574

575

576

577

578

579

580

581

582

583 interventions. J Clin Nurs. 2003;12(1):77-84. doi:10.1046/j.1365-2702.2003.00662.x.

14. Merlin T, Weston A, Tooher R. Extending an evidence hierarchy to include topics other than treatment: revising the Australian 'levels of evidence'. BMC Med Res Methodol. 2009;9(1):34-34. doi:10.1186/1471-2288-9-34.

15. Thomas J, Harden A. Methods for the thematic synthesis of qualitative research in systematic reviews. BMC Med Res Methodol. 2008;8(1):45-45. doi:10.1186/1471-2288-8-45.

16. Arksey H, O'Malley L. Scoping studies: towards a methodological framework. Int J Soc Res Methodol. 2005;8(1):19-32. doi:10.1080/1364557032000119616.

17. Abate M, Salini V. Mid-portion Achilles tendinopathy in runners with metabolic disorders. Eur $J$ Orthop Surg Traumatol. 2019;29(3):697-703. doi:10.1007/s00590-018-2336-2.

18. Aiyegbusi AI, Tella BA, Sanusi GA. Is genu varum a risk factor for the prevalence and severity of achilles tendinopathy? A cross-sectional study of Nigerian elite track and field athletes. Niger Postgrad Med J. 2020;27(2):87-92. doi:10.4103/npmj.npmj_179_19.

19. Aldridge T. Diagnosing heel pain in adults. Am Fam Physician. 2004;70(2):332-338.

20. Alfredson H. Chronic midportion Achilles tendinopathy: an update on research and treatment. Clin Sports Med. 2003;22(4):727-741.

21. Alfredson $\mathrm{H}$, Cook J. A treatment algorithm for managing Achilles tendinopathy: new treatment options. Br J Sports Med. 2007;41(4):211-216.

22. Alfredson H, Spang C. Clinical presentation and surgical management of chronic Achilles tendon disorders - A retrospective observation on a set of consecutive patients being operated by the same orthopedic surgeon. Foot Ankle Surg. 2018;24(6):490-494. doi:10.1016/j.fas.2017.05.011.

23. Aronow MS. Posterior heel pain (retrocalcaneal bursitis, insertional and noninsertional Achilles tendinopathy). Clin Podiatr Med Surg. 2005;22(1):19-43. doi:10.1016/j.cpm.2004.08.003.

24. Asplund CA, Best TM. Achilles tendon disorders. BMJ. 2013;346(7899):29-33. doi:10.1136/bmj.f1262.

25. Azevedo LB, Lambert MI, Vaughan CL, O'Connor CM, Schwellnus MP. Biomechanical variables associated with Achilles tendinopathy in runners. Br J Sports Med. 2009;43(4):288-292. doi:10.1136/bjsm.2008.053421.

26. Bains BS, Porter K. Lower limb tendinopathy in athletes. Trauma. 2006;8(4):213-224. doi:10.1177/1460408606078110.

27. Barge-Caballero E, Crespo-Leiro MG, Paniagua-Martín MJ, et al. Quinolone-related Achilles tendinopathy in heart transplant patients: incidence and risk factors. J Heart Lung Transplant. 2008;27(1):46-51. doi:10.1016/j.healun.2007.09.021.

28. Barker-Davies RM, Nicol A, McCurdie I, et al. Study protocol: a double blind randomised control trial of high volume image guided injections in Achilles and patellar tendinopathy in a young active population. BMC Musculoskelet Disord. 2017;18(1) doi:10.1186/s12891-017-15647.

29. Baskerville R, McCartney DE, McCartney SM, Dawes H, Tan GD. Tendinopathy in type 2 diabetes: a condition between specialties? Br J Gen Pract. 2018;68(677):593-594. doi:10.3399/bjgp18X700169.

30. Benazzo F, Todesca A, Ceciliani L. Achilles' tendon tendinitis and heel pain. Oper Tech Sports Med. 1997;5(3):179-188. 
584 31. Benito E. Physiotherapy's protocol to approach the insertional achilles tendinopathy. Journal of

585

586

587

588

589

590

591

592

593

594

595

596

597

598

599

600

601

602

603

604

605

606

607

608

609

610

611

612

613

614

615

616

617

618

619

620

621

622

623

624

625

626

627 Human Sport and Exercise. 2016;11(3):358-366.

32. Bhatty UN, Khan SHM, Zubairy AI. Managing the patient with heel pain. Br J Hosp Med. 2019;80(4):196-200. doi:10.12968/hmed.2019.80.4.196.

33. Bjordal JM, Lopes-Martins RAB, Iversen VV. A randomised, placebo controlled trial of low level laser therapy for activated Achilles tendinitis with microdialysis measurement of peritendinous prostaglandin E2 concentrations. Br J Sports Med. 2006;40(1):76-80.

34. Boesen AP, Hansen R, Boesen MI, Malliaras P, Langberg H. Effect of high-volume injection, platelet-rich plasma, and sham treatment in chronic midportion Achilles tendinopathy: a randomized double-blinded prospective study. Am J Sports Med. 2017;45(9):2034-2043. doi: $10.1177 / 0363546517702862$.

35. Borda J, Selhorst M. The use of compression tack and flossing along with lacrosse ball massage to treat chronic Achilles tendinopathy in an adolescent athlete: a case report. J Man Manip Ther. 2017;25(1):57-61. doi:10.1080/10669817.2016.1159403.

36. Brown R, Orchard J, Kinchington M, Hooper A, Nalder G. Aprotinin in the management of Achilles tendinopathy: a randomised controlled trial. Br J Sports Med. 2006;40(3):275-279. doi:10.1136/bjsm.2005.021931.

37. Carcia CR, Martin RL, Houck J, Wukich DK. Clinical Guidelines. Achilles pain, stiffness, and muscle power deficits: Achilles tendinitis. J Orthop Sports Phys Ther. 2010;40(9):A1-A26. doi:10.2519/jospt.2010.0305.

38. Cassel M, Risch L, Intziegianni K, et al. Incidence of Achilles and patellar tendinopathy in adolescent elite athletes. Int J Sports Med. 2018;39(9):726-732. doi:10.1055/a-0633-9098.

39. Chazan IM. Achilles tendinitis part II: clinical examination, differential diagnosis, and approaches to management. J Man Manip Ther. 1998;6(2):70-77. doi:10.1179/jmt.1998.6.2.70.

40. Cheng Y, Zhang J, Cai Y. Utility of ultrasonography in assessing the effectiveness of extracorporeal shock wave therapy in insertional Achilles tendinopathy. Biomed Res Int. 2016;2016 doi: $10.1155 / 2016 / 2580969$.

41. Chester R, Costa ML, Shepstone L, Cooper A, Donell ST. Eccentric calf muscle training compared with therapeutic ultrasound for chronic Achilles tendon pain-A pilot study. Man Ther. 2008;13(6):484-491.

42. Chimenti RL, Chimenti PC, Buckley MR, Houck JR, Flemister AS. Utility of ultrasound for imaging osteophytes in patients with insertional Achilles tendinopathy. Arch Phys Med Rehabil. 2016;97(7):1206-1209. doi:10.1016/j.apmr.2015.12.009.

43. Chimenti RL, Cychosz CC, Hall MM, Phisitkul P. Current concepts review update: insertional Achilles tendinopathy. Foot Ankle Int. 2017;38(10):1160-1169.

44. Chimenti RL, Hall MM, Dilger CP, Merriwether EN, Wilken JM, Sluka KA. Local anesthetic injection resolves movement pain, motor dysfunction, and pain catastrophizing in individuals with chronic Achilles tendinopathy: a nonrandomized clinical trial. J Orthop Sports Phys Ther. 2020;50(6):334-343. doi:10.2519/jospt.2020.9242.

45. Cook JL, Khan KM, Purdam C. Achilles tendinopathy. Man Ther. 2002;7(3):121-130. doi:10.1054/math.2002.0458.

46. Coombes BK, Tucker K, Vicenzino B, et al. Achilles and patellar tendinopathy display opposite changes in elastic properties: a shear wave elastography study. Scand J Med Sci Sports. 2018;28(3):1201-1208. doi:10.1111/sms.12986. 
628 47. Courville XF, Coe MP, Hecht PJ. Current concepts review: noninsertional Achilles tendinopathy.

629

630

631

632

633

634

635

636

637

638

639

640

641

642

643

644

645

646

647

648

649

650

651

652

653

654

655

656

657

658

659

660

661

662

663

664

665

666

667

668

669

670

671

Foot Ankle Int. 2009;30(11):1132-1142. doi:10.3113/FAI.2009.1132.

48. Creaby MW, Honeywill C, Franettovich Smith MM, Schache AG, Crossley KM. Hip biomechanics are altered in male runners with Achilles tendinopathy. Med Sci Sports Exerc. 2017;49(3):549-554. doi:10.1249/MSS.0000000000001126.

49. Crill MT, Berlet G, Hyer C. Plantar flexor muscle architecture changes as a result of eccentric exercise in patients with Achilles tendinosis. Foot Ankle Spec. 2014;7(6):460-465. doi:10.1177/1938640014539812.

50. De Jonge S, Van Den Berg C, De Vos RJ, et al. Incidence of midportion Achilles tendinopathy in the general population. Br J Sports Med. 2011;45(13):1026-1028. doi:10.1136/bjsports-2011090342.

51. De Marchi A, Pozza S, Cenna E, et al. In Achilles tendinopathy, the neovascularization, detected by contrast-enhanced ultrasound (CEUS), is abundant but not related to symptoms. Knee Surg Sports Traumatol Arthrosc. 2018;26(7):2051-2058. doi:10.1007/s00167-017-4710-8.

52. Den Hartog BD. Insertional achilles tendinosis: pathogenesis and treatment. Foot Ankle Clin. 2009;14(4):639-650. doi:10.1016/j.fcl.2009.08.005.

53. Divani K, Chan O, Padhiar N, et al. Site of maximum neovascularisation correlates with the site of pain in recalcitrant mid-tendon Achilles tendinopathy. Man Ther. 2010;15(5):463-468. doi:10.1016/j.math.2010.03.011.

54. Docking SI, Rosengarten SD, Daffy J, Cook J. Structural integrity is decreased in both Achilles tendons in people with unilateral Achilles tendinopathy. J Sci Med Sport. 2015;18(4):383-387.

55. Duthon VB, Lübbeke A, Duc SR, Stern R, Assal M. Noninsertional Achilles tendinopathy treated with gastrocnemius lengthening. Foot Ankle Int. 2011;32(4):375-379.

doi:10.3113/FAI.2011.0375.

56. Ebbesen BH, Mølgaard CM, Olesen JL, Gregersen HE, Simonsen O. No beneficial effect of Polidocanol treatment in Achilles tendinopathy: a randomised controlled trial. Knee Surg Sports Traumatol Arthrosc. 2018;26(7):2038-2044. doi:10.1007/s00167-017-4675-7.

57. Eckenrode BJ, Kietrys DM, Stackhouse SK. Pain sensitivity in chronic Achilles tendinopathy. Int J Sports Phys Ther. 2019;14(6):945-956.

58. Feilmeier M. Noninsertional Achilles tendinopathy pathologic background and clinical examination. Clin Podiatr Med Surg. 2017;34(2):129-136. doi:10.1016/j.cpm.2016.10.003.

59. Finnamore E, Waugh C, Solomons L, Ryan M, West C, Scott A. Transverse tendon stiffness is reduced in people with Achilles tendinopathy: a cross-sectional study. PLoS One. 2019;14(2) doi:10.1371/journal.pone.0211863.

60. Florit D, Pedret C, Casals M, Malliaras P, Sugimoto D, Rodas G. Incidence of tendinopathy in team sports in a multidisciplinary sports club over 8 seasons. J Sports Sci Med. 2019;18(4):780788.

61. Fredericson M. Common injuries in runners: diagnosis, rehabilitation and prevention. Sports Med. 1996;21(1):49-72. doi:10.2165/00007256-199621010-00005.

62. Furia JP, Rompe JD. Extracorporeal shock wave therapy in the treatment of chronic plantar fasciitis and Achilles tendinopathy. Curr Opin Orthop. 2007;18(2):102-111.

63. Gärdin A, Rasinski P, Berglund J, Shalabi A, Schulte H, Brismar TB. T2* relaxation time in Achilles tendinosis and controls and its correlation with clinical score. J Magn Reson Imaging. 2016;43(6):1417-1422. doi:10.1002/jmri.25104.

Peer] reviewing PDF | (2021:05:60805:1:0:NEW 12 Aug 2021) 
672 64. Gatz M, Betsch M, Dirrichs T, et al. Eccentric and isometric exercises in Achilles tendinopathy

673

674

675

676

677

678

679

680

681

682

683

684

685

686

687

688

689

690

691

692

693

694

695

696

697

698

699

700

701

702

703

704

705

706

707

708

709

710

711

712

713

714 evaluated by the VISA-A score and shear wave elastography. Sports Health. 2020; doi:10.1177/1941738119893996.

65. Habets B, van Cingel REH, Backx FJG, Huisstede BMA. Alfredson versus Silbernagel exercise therapy in chronic midportion Achilles tendinopathy: study protocol for a randomized controlled trial. BMC Musculoskelet Disord. 2017;18:1-9. doi:10.1186/s12891-017-1656-4.

66. Hasani F, Haines TP, Munteanu SE, Vicenzino B, Malliaras P. Efficacy of different load intensity and time-under-tension calf loading protocols for Achilles tendinopathy (the LOADIT trial): protocol for a randomised pilot study. Pilot Feasibility Stud. 2020;6:99. doi:10.1186/s40814-02000639-5.

67. Hernández-Sánchez S, Poveda-Pagán EJ, Alakhdar-Mohmara Y, Hidalgo MD, Fernández-DeLas-Peñas C, Arias-Buría JL. Cross-cultural adaptation of the Victorian Institute of Sport Assessment-Achilles (VISA-A) questionnaire for spanish athletes with Achilles tendinopathy. $J$ Orthop Sports Phys Ther. 2018;48(2):111-120. doi:10.2519/jospt.2018.7402.

68. Holmes GB, Lin J. Etiologic factors associated with symptomatic Achilles tendinopathy. Foot Ankle Int. 2006;27(11):952-959. doi:10.1177/107110070602701115.

69. Horn A, McCollum G. Achilles tendinopathy - Part 1: aetiology, diagnosis and non-surgical management. The South African Orthopaedic Journal (SAOJ). 2015;14(3):24-31. doi:10.17159/2309-8309/2015/v14n3a2.

70. $\mathrm{Hu} \mathrm{CT}$, Flemister AS. Insertional Achilles tendinopathy: surgical options. Oper Tech Orthop. 2008;18(4):247-253.

71. Hutchison AM, Beard D, Pallister I, Topliss CJ, Williams P. Is physiotherapy effective for patients with a chronic mid-body Achilles tendinopathy? a systematic review of non-surgical and non-pharmacological interventions. Int Musculoskelet Med. 2011;33(4):152-160. doi:10.1179/1753615411Y.0000000010.

72. Irwin TA. Current concepts review: insertional Achilles tendinopathy. Foot Ankle Int. 2010;31(10):933-939.

73. Järvinen TAH, Kannus P, Paavola M, Järvinen TLN, Józsa L, Järvinen M. Achilles tendon injuries. Curr Opin Rheumatol. 2001;13(2):150-155. doi:10.1097/00002281-200103000-00009.

74. Jayaseelan DJ, Weber MJ, Jonely H. Potential nervous system sensitization in patients with persistent lower extremity tendinopathies: 3 case reports. J Orthop Sports Phys Ther. 2019;49(4):272-279.

75. Jewson JL, Lambert EA, Docking S, Storr M, Lambert GW, Gaida JE. Pain duration is associated with increased muscle sympathetic nerve activity in patients with Achilles tendinopathy. Scand J Med Sci Sports. 2017;27(12):1942-1949. doi:10.1111/sms.12820.

76. Jowett CRJ, Richmond A, Bedi HS. Paratendinous scraping and excision of plantaris for Achilles tendinopathy. Tech Foot Ankle Surg. 2018;17(1):27-30. doi:10.1097/BTF.0000000000000168.

77. Jukes CP, Scott G, Solan MC. Posterior heel pain. Orthop Trauma. 2020;34(1):3-9. doi:10.1016/j.mporth.2019.11.001.

78. Kader D, Saxena A, Movin T, Maffulli N. Achilles tendinopathy: some aspects of basic science and clinical management. Br J Sports Med. 2002;36(4):239-249. doi:10.1136/bjsm.36.4.239.

79. Karjalainen PT, Soila K, Aronen HJ, et al. MR imaging of overuse injuries of the Achilles tendon. AJR Am J Roentgenol. 2000;175(1):251-260. doi:10.2214/ajr.175.1.1750251. 
715 80. Khan KM, Forster BB, Robinson J, et al. Are ultrasound and magnetic resonance imaging of

716

717

718

719

720

721

722

723

724

725

726

727

728

729

730

731

732

733

734

735

736

737

738

739

740

741

742

743

744

745

746

747

748

749

750

751

752

753

754

755

756

757 value in assessment of Achilles tendon disorders? A two year prospective study. Br J Sports Med. 2003;37(2):149-153. doi:10.1136/bjsm.37.2.149.

81. Knobloch K. Eccentric training in Achilles tendinopathy: is it harmful to tendon microcirculation? Br J Sports Med. 2007;41(6):e2-e2.

82. Knobloch K, Kraemer R, Jagodzinski M, Zeichen J, Meller R, Vogt PM. Eccentric training decreases paratendon capillary blood flow and preserves paratendon oxygen saturation in chronic Achilles tendinopathy. J Orthop Sports Phys Ther. 2007;37(5):269-276.

83. Knobloch K, Schreibmueller L, Longo UG, Vogt PM. Eccentric exercises for the management of tendinopathy of the main body of the Achilles tendon with or without an AirHeel Brace. A randomized controlled trial. B: Effects of compliance. Disabil Rehabil. 2008;30(20-22):16921696. doi:10.1080/09638280701785676.

84. Kragsnaes MS, Fredberg U, Stribolt K, Kjaer SG, Bendix K, Ellingsen T. Stereological quantification of immune-competent cells in baseline biopsy specimens from Achilles tendons: results from patients with chronic tendinopathy followed for more than 4 years. Am J Sports Med. 2014;42(10):2435-2445.

85. Krogh TP, Ellingsen T, Christensen R, Jensen P, Fredberg U. Ultrasound-guided injection therapy of Achilles tendinopathy with platelet-rich plasma or saline. Am J Sports Med. 2016;44(8):1990-1997. doi:10.1177/0363546516647958.

86. Lakshmanan P, O'Doherty DP. Chronic Achilles tendinopathy: treatment with extracorporeal shock waves. Foot Ankle Surg. 2004;10(3):125-130. doi:10.1016/j.fas.2004.04.001.

87. Leung JLY, Griffith JF. Sonography of chronic achilles tendinopathy: a case-control study. J Clin Ultrasound. 2008;36(1):27-32. doi:10.1002/jcu.20388.

88. Lohrer H, Nauck T. Cross-cultural adaptation and validation of the VISA-A questionnaire for German-speaking Achilles tendinopathy patients. BMC Musculoskelet Disord. 2009;10:134-134. doi:10.1186/1471-2474-10-134.

89. Longo UG, Rittweger J, Garau G, et al. No influence of age, gender, weight, height, and impact profile in achilles tendinopathy in masters track and field athletes. Am J Sports Med. 2009;37(7):1400-1405. doi:10.1177/0363546509332250.

90. Longo UG, Ronga M, Maffulli N. Achilles tendinopathy. Sports Med Arthrosc Rev. 2009;17(2):112-126.

91. Maffulli N, Giai Via A, Oliva F. Chronic Achilles tendon disorders. Clin Sports Med. 2015;34(4):607-624.

92. Maffulli N, Giuseppe Longo U, Denaro V. Achilles tendinopathy in dancers. J Dance Med Sci. 2012;16(3):92-100.

93. Maffulli N, Kader D. Tendinopathy of tendo achillis. J Bone Joint Surg Br. 2002;84B(1):1-8.

94. Maffulli N, Kenward MG, Testa V, Capasso G, Regine R, King JB. Clinical diagnosis of Achilles tendinopathy with tendinosis. Clin J Sport Med. 2003;13(1):11-15. doi:10.1097/00042752200301000-00003.

95. Maffulli N, Longo UG, Campi S, Denaro V. Achilles tendinopathy. Evidence-Based Orthopedics.2011:872-878.

96. Maffulli N, Longo UG, Kadakia A, Spiezia F. Achilles tendinopathy. Foot Ankle Surg. 2020;26(3):240-249. doi:10.1016/j.fas.2019.03.009. 
758 97. Maffulli N, Longo UG, Petrillo S, Denaro V. Management of tendinopathies of the foot and

759

760

761

762

763

764

765

766

767

768

769

770

771

772

773

774

775

776

777

778

779

780

781

782

783

784

785

786

787

788

789

790

791

792

793

794

795

796

797

798

799 ankle. Orthop Trauma. 2012;26(4):259-264. doi:10.1016/j.mporth.2012.05.008.

98. Maffulli N, Longo UG, Testa V, Oliva F, Capasso G, Denaro V. Italian translation of the VISA-A score for tendinopathy of the main body of the Achilles tendon. Disabil Rehabil. 2008;30(2022):1635-1639. doi:10.1080/09638280701785965.

99. Maffulli N, Saxena A, Wagner E, Torre G. Achilles insertional tendinopathy: state of the art. $J$ ISAKOS. 2019;4(1):48-57. doi:10.1136/jisakos-2017-000144.

100. Maffulli N, Sharma P, Luscombe KL. Achilles tendinopathy: aetiology and management. J R Soc Med. 2004;97(10):472-476. doi:10.1258/jrsm.97.10.472.

101. Maffulli N, Via AG, Oliva F. Achilles injuries in the athlete: noninsertional. Oper Tech Sports Med. 2014;22(4):321-330.

102. Maffulli N, Walley G, Sayana M, Longo UG, Denaro V. Eccentric calf muscle training in athletic patients with Achilles tendinopathy. Disabil Rehabil. 2008;30(20-22):1677-1684. doi:10.1080/09638280701786427.

103. Mafi N, Lorentzon R, Alfredson H. Superior short-term results with eccentric calf muscle training compared to concentric training in a randomized prospective multicenter study on patients with chronic Achilles tendinosis. Knee Surg Sports Traumatol Arthrosc. 2001;9(1):42-47. doi:10.1007/s001670000148.

104. Magnussen RA, Dunn WR, Thomson AB. Nonoperative treatment of midportion achilles tendinopathy: a systematic review. Clin J Sport Med. 2009;19(1):54-64. doi:10.1097/JSM.0b013e31818ef090.

105. Mansur NSB, Baumfeld T, Villalon F, et al. Shockwave therapy associated with eccentric strengthening for Achilles insertional tendinopathy: a prospective study. Foot Ankle Spec. 2019;12(6):540-545. doi:10.1177/1938640019826673.

106. Mansur NSB, Faloppa F, Belloti JC, et al. Shock wave therapy associated with eccentric strengthening versus isolated eccentric strengthening for Achilles insertional tendinopathy treatment: a double-blinded randomised clinical trial protocol. BMJ Open. 2017;7(1) doi:10.1136/bmjopen-2016-013332.

107. Mantovani L, Maestroni L, Bettariga F, Gobbo M, Lopomo NF, McLean S. Does isometric exercise improve leg stiffness and hop pain in subjects with Achilles tendinopathy? A feasibility study. Phys Ther Sport. 2020;46:234-242. doi:10.1016/j.ptsp.2020.09.005.

108. Martin RL, Chimenti R, Cuddeford T, et al. Achilles pain, stiffness, and muscle power deficits: midportion Achilles tendinopathy revision 2018. J Orthop Sports Phys Ther. 2018;48(5):A1-A38. doi:10.2519/jospt.2018.0302.

109. Mayer F, Hirschmüller A, Müller S, Schuberth M, Baur H. Effects of short-term treatment strategies over 4 weeks in Achilles tendinopathy. Br J Sports Med. 2007;41(7):e6. doi:10.1136/bjsm.2006.031732.

110. McCormack J, Underwood F, Slaven E, Cappaert T. The minimum clinically important difference on the VISA-A and LEFS for patients with insertional Achilles tendinopathy. Int $J$ Sports Phys Ther. 2015;10(5):639-644.

111. McShane JM, Ostick B, McCabe F. Noninsertional Achilles tendinopathy: pathology and management. Curr Sports Med Rep. 2007;6(5):288-292. doi:10.1007/s11932-007-0064-1. 
800 112. Murawski CD, Smyth NA, Newman H, Kennedy JG. A single platelet-rich plasma injection for

801

802

803

804

805

806

807

808

809

810

811

812

813

814

815

816

817

818

819

820

821

822

823

824

825

826

827

828

829

830

831

832

833

834

835

836

837

838

839

840

841

842 chronic midsubstance achilles tendinopathy: a retrospective preliminary analysis. Foot Ankle Spec. 2014;7(5):372-376. doi:10.1177/1938640014532129.

113. Nadeau MJ, Desrochers A, Lamontagne M, Larivière C, Gagnon DH. Quantitative ultrasound imaging of Achilles tendon integrity in symptomatic and asymptomatic individuals: reliability and minimal detectable change. J Foot Ankle Res. 2016;9(1) doi:10.1186/s13047-016-0164-3.

114. Neeter C, Thomeé R, Silbernagel KG, Thomeé P, Karlsson J. Iontophoresis with or without dexamethazone in the treatment of acute Achilles tendon pain. Scand J Med Sci Sports. 2003;13(6):376-382. doi:10.1046/j.1600-0838.2003.00305.x.

115. Nichols AW. Achilles tendinitis in running athletes. J Am Board Fam Med. 1989;2(3):196-203.

116. Nunes De Mesquita G, Nicacio Medeiros De Oliveira M, Rodrigues Matoso AE, Galvao De Moura Filho A, Ribeiro De Oliveira R. Cross-cultural adaptation and measurement properties of the Brazilian Portuguese version of the Victorian Institute of Sport Assessment-Achilles (VISAA) questionnaire. J Orthop Sports Phys Ther. 2018;48(7):567-573.

117. O'Neill S, Radia J, Bird K, et al. Acute sensory and motor response to 45-s heavy isometric holds for the plantar flexors in patients with Achilles tendinopathy. Knee Surg Sports Traumatol Arthrosc. 2019;27(9):2765-2773.

118. Oloff L, Elmi E, Nelson J, Crain J. Retrospective analysis of the effectiveness of platelet-rich plasma in the treatment of Achilles tendinopathy: pretreatment and posttreatment correlation of magnetic resonance imaging and clinical assessment. Foot Ankle Spec. 2015;8(6):490-497. doi:10.1177/1938640015599033.

119. Ooi CC, Schneider ME, Malliaras P, Chadwick M, Connell DA. Diagnostic performance of axialstrain sonoelastography in confirming clinically diagnosed Achilles tendinopathy: comparison with B-Mode ultrasound and color doppler imaging. Ultrasound Med Biol. 2015;41(1):15-25. doi:10.1016/j.ultrasmedbio.2014.08.019.

120. Paavola M, Kannus P, Järvinen TAH, Khan K, Józsa L, Järvinen M. Achilles tendinopathy. $J$ Bone Joint Surg Am. 2002;84(11):2062-2076.

121. Paavola M, Kannus P, Orava S, Pasanen M, Järvinen M. Surgical treatment for chronic Achilles tendinopathy: a prospective seven month follow up study. Br J Sports Med. 2002;36(3):178-182.

122. Paavola M, Kannus P, Paakkala T, Pasanen M, Jarvinen M. Long-term prognosis of patients with Achilles tendinopathy: an observational 8-year follow-up study. Am J Sports Med. 2000;28(5):634-642. doi:10.1177/03635465000280050301.

123. Paoloni JA, Appleyard RC, Nelson J, Murrell GAC. Topical glyceryl trinitrate treatment of chronic noninsertional Achilles tendinopathy: a randomized, double-blind, placebo-controlled trial. J Bone Joint Surg Am. 2004;86(5):916-922.

124. Papa JA. Conservative management of Achilles tendinopathy: a case report. J Can Chiropr Assoc. 2012;56(3):216-224.

125. Pedowitz D, Beck D. Presentation, diagnosis, and nonsurgical treatment options of the anterior tibial tendon, posterior tibial tendon, peroneals, and Achilles. Foot Ankle Clin. 2017;22(4):677687. doi:10.1016/j.fcl.2017.07.012.

126. Petersen W, Welp R, Rosenbaum D. Chronic Achilles tendinopathy: a prospective randomized study comparing the therapeutic effect of eccentric training, the AirHeel brace, and a combination of both. Am J Sports Med. 2007;35(10):1659-1667. doi:10.1177/0363546507303558. 
843 127. Pingel J, Harrison A, Simonsen L, Suetta C, Bülow J, Langberg H. The microvascular volume of

844

845

846

847

848

849

850

851

852

853

854

855

856

857

858

859

860

861

862

863

864

865

866

867

868

869

870

871

872

873

874

875

876

877

878

879

880

881

882

883

884

885 the achilles tendon is increased in patients with tendinopathy at rest and after a 1-hour treadmill run. Am J Sports Med. 2013;41(10):2400-2408. doi:10.1177/0363546513498988.

128. Post AA, Rio EK, Sluka KA, et al. Effect of pain education and exercise on pain and function in chronic Achilles tendinopathy: protocol for a double-blind, placebo-controlled randomized trial. JMIR Res Protoc. 2020;9(11):e19111. doi:10.2196/19111.

129. Praet SFE, Ong JH, Purdam C, et al. Microvascular volume in symptomatic Achilles tendons is associated with VISA-A score. J Sci Med Sport. 2018;21(12):1185-1191. doi:10.1016/j.jsams.2018.05.013.

130. Rabello LM, van den Akker-Scheek I, Kuipers IF, Diercks RL, Brink MS, Zwerver J. Bilateral changes in tendon structure of patients diagnosed with unilateral insertional or midportion achilles tendinopathy or patellar tendinopathy. Knee Surg Sports Traumatol Arthrosc. 2020;28(5):1631-1638. doi:10.1007/s00167-019-05495-2.

131. Rasmussen S, Christensen M, Mathiesen I, Simonson O. Shockwave therapy for chronic Achilles tendinopathy: a double-blind, randomized clinical trial of efficacy. Acta Orthop. 2008;79(2):249256. doi:10.1080/17453670710015058.

132. Reid D, McNair PJ, Johnson S, Potts G, Witvrouw E, Mahieu N. Electromyographic analysis of an eccentric calf muscle exercise in persons with and without Achilles tendinopathy. Phys Ther Sport. 2012;13(3):150-155. doi:10.1016/j.ptsp.2011.08.003.

133. Reiter M, Ulreich N, Dirisamer A, Tscholakoff D, Bocek RA. Colour and power doppler sonography in symptomatic achilles tendon disease. Int J Sports Med. 2004;25(4):301-305. doi:10.1055/s-2004-815828.

134. Romero-Morales C, Martín-Llantino PJ, Calvo-Lobo C, et al. Ultrasonography features of the plantar fascia complex in patients with chronic non-insertional achilles tendinopathy: a casecontrol study. Sensors (Basel). 2019;19(9) doi:10.3390/s19092052.

135. Rompe JD, Furia J, Maffulli N. Eccentric loading versus eccentric loading plus shock-wave treatment for midportion achilles tendinopathy: a randomized controlled trial. Am J Sports Med. 2009;37(3):463-470. doi:10.1177/0363546508326983.

136. Rompe JD, Furia J, Maffulli N, Rompe JD, Furia J, Maffulli N. Eccentric loading compared with shock wave treatment for chronic insertional achilles tendinopathy. A randomized, controlled trial. J Bone Joint Surg Am. 2008;90(1):52-61. doi:10.2106/JBJS.F.01494.

137. Rompe JD, Nafe B, Furia JP, Maffulli N. Eccentric loading, shock-wave treatment, or a wait-andsee policy for tendinopathy of the main body of tendo Achillis: a randomized controlled trial. Am J Sports Med. 2007;35(3):374-383. doi:10.1177/0363546506295940.

138. Roos EM, Engström M, Lagerquist A, Söderberg B. Clinical improvement after 6 weeks of eccentric exercise in patients with mid-portion Achilles tendinopathy: a randomized trial with 1year follow-up. Scand J Med Sci Sports. 2004;14(5):286-295. doi:10.1111/j.16000838.2004.378.x.

139. Ryan M, Grau S, Krauss I, Maiwald C, Taunton J, Hostmann T. Kinematic analysis of runners with Achilles mid-portion tendinopathy. Foot Ankle Int. 2009;30(12):1190-1195. doi:10.3113/FAI.2009.1190.

140. Saini SS, Reb CW, Chapter M, Daniel JN. Achilles tendon disorders. J Am Osteopath Assoc. 2015;115(11):670-676. doi:10.7556/jaoa.2015.138. 
886 141. Santamato A, Beatrice R, Micello MF, et al. Power doppler ultrasound findings before and after

887

888

889

890

891

892

893

894

895

896

897

898

899

900

901

902

903

904

905

906

907

908

909

910

911

912

913

914

915

916

917

918

919

920

921

922

923

924

925

926

927 focused extracorporeal shock wave therapy for Achilles tendinopathy: a pilot study on pain reduction and neovascularization effect. Ultrasound Med Biol. 2019;45(5):1316-1323. doi:10.1016/j.ultrasmedbio.2018.12.009.

142. Sayana M, Maffulli N. Eccentric calf muscle training in non-athletic patients with achilles tendinopathy. J Sci Med Sport. 2007;10(1):52-58.

143. Scholes M, Stadler S, Connell D, et al. Men with unilateral Achilles tendinopathy have impaired balance on the symptomatic side. J Sci Med Sport. 2018;21(5):479-482. doi:10.1016/j.jsams.2017.09.594.

144. Scott A, Huisman E, Khan K. Conservative treatment of chronic Achilles tendinopathy. CMAJ. 2011;183(10):1159-1165. doi:10.1503/cmaj.101680.

145. Sengkerij PM, de Vos R-J, Weir A, Bert JGvW, Tol JL. Interobserver Reliability of Neovascularization Score Using Power Doppler Ultrasonography in Midportion Achilles Tendinopathy. Am J Sports Med. 2009;37(8):1627-1631. doi:10.1177/0363546509332255.

146. Sharma P, Maffulli N. Understanding and managing Achilles tendinopathy. Br J Hosp Med. 2006;67(2):64-67.

147. Silbernagel K, Thomeé R, Eriksson BI, Karlsson J. Full symptomatic recovery does not ensure full recovery of muscle-tendon function in patients with Achilles tendinopathy. Br J Sports Med. 2007;41(4):276-280.

148. Silbernagel KG, Thomeé R, Thomeé P, Karlsson J. Eccentric overload training for patients with chronic Achilles tendon pain: a randomised controlled study with reliability testing of the evaluation methods. Scand J Med Sci Sports. 2001;11(4):197-206. doi:10.1034/j.16000838.2001.110402.x.

149. Simpson MR, Howard TM. Tendinopathies of the foot and ankle. Am Fam Physician. 2009;80(10):1107-1114.

150. Solomons L, Lee JJY, Bruce M, White LD, Scott A. Intramuscular stimulation vs sham needling for the treatment of chronic midportion Achilles tendinopathy: a randomized controlled clinical trial. PLoS One. 2020;15(9):e0238579. doi:10.1371/journal.pone.0238579.

151. Sorosky B, Press J, Plastaras C, Rittenberg J. The practical management of Achilles tendinopathy. Clin J Sport Med. 2004;14(1):40-44. doi:10.1097/00042752-200401000-00007.

152. Stenson JF, Reb CW, Daniel JN, Saini SS, Albana MF. Predicting failure of nonoperative treatment for insertional Achilles tendinosis. Foot Ankle Spec. 2018;11(3):252-255. doi:10.1177/1938640017729497.

153. Stergioulas A, Stergioula M, Aarskog R, Lopes-Martins RA, Bjordal JM. Effects of low-level laser therapy and eccentric exercises in the treatment of recreational athletes with chronic achilles tendinopathy. Am J Sports Med. 2008;36(5):881-887. doi:10.1177/0363546507312165.

154. Syvertson P, Dietz E, Matocha M, et al. A treatment-based classification algorithm to treat achilles tendinopathy: an exploratory case series. J Sport Rehabil. 2017;26(3):260-268. doi:10.1123/jsr.2016-0033.

155. Tan SC, Chan O. Achilles and patellar tendinopathy: current understanding of pathophysiology and management. Disabil Rehabil. 2008;30(20-22):1608-1615.

doi:10.1080/09638280701792268. 
928

929

930

931

932

933

934

935

936

937

938

939

940

941

942

943

944

945

946

947

948

949

950

951

952

953

954

955

956

957

958

959

960

961

962

963

964

965

966

967

968

969

970

156. Thomas JL, Christensen JC, Kravitz SR, et al. The diagnosis and treatment of heel pain: a clinical practice guideline-revision 2010. J Foot Ankle Surg. 2010;49(3):S1-S19.

doi:10.1053/j.jfas.2010.01.001.

157. Turner J, Malliaras P, Goulis J, Mc Auliffe S. "It's disappointing and it's pretty frustrating, because it feels like it's something that will never go away." A qualitative study exploring individuals' beliefs and experiences of Achilles tendinopathy. PLoS One. 2020;15(5):e0233459. doi:10.1371/journal.pone.0233459.

158. Vallance P, Hasani F, Crowley L, Malliaras P. Self-reported pain with single leg heel raise or single leg hop offer distinct information as measures of severity in men with midportion and insertional Achilles tendinopathy: an observational cross-sectional study. Phys Ther Sport. 2020;47:23-31. doi:10.1016/j.ptsp.2020.10.009.

159. van der Vlist AC, van Veldhoven PLJ, van Oosterom RF, Verhaar JAN, de Vos RJ. Isometric exercises do not provide immediate pain relief in Achilles tendinopathy: a quasi-randomized clinical trial. Scand J Med Sci Sports. 2020;30(9):1712-1721. doi:10.1111/sms.13728.

160. van der Vlist AC, Veen JM, van Oosterom RF, van Veldhoven PLJ, Verhaar JAN, de Vos RJ. Ultrasound doppler flow in patients with chronic midportion Achilles tendinopathy: is surface area quantification a reliable method? J Ultrasound Med. 2020;39(4):731-739.

doi:10.1002/jum.15152.

161. van Sterkenburg MN, Kerkhoffs GM, van Dijk CN, van Sterkenburg MN, Kerkhoffs GMMJ, van Dijk CN. Good outcome after stripping the plantaris tendon in patients with chronic mid-portion Achilles tendinopathy. Knee Surg Sports Traumatol Arthrosc. 2011;19(8):1362-1366. doi:10.1007/s00167-011-1514-0.

162. Verrall G, Schofield S, Brustad T. Chronic achilles tendinopathy treated with eccentric stretching program. Foot Ankle Int. 2011;32(9):843-849. doi:10.3113/FAI.2011.0843.

163. von Wehren L, Pokorny K, Blanke F, Sailer J, Majewski M. Injection with autologous conditioned serum has better clinical results than eccentric training for chronic Achilles tendinopathy. Knee Surg Sports Traumatol Arthrosc. 2019;27(9):2744-2753.

164. Wang HK, Lin KH, Su SC, Shih TTF, Huang YC. Effects of tendon viscoelasticity in Achilles tendinosis on explosive performance and clinical severity in athletes. Scand J Med Sci Sports. 2012;22(6):e147-e155.

165. Wei M, Liu Y, Li Z, Wang Z. Comparison of clinical efficacy among endoscopy-assisted radiofrequency ablation, extracorporeal shockwaves, and eccentric exercises in treatment of insertional achilles tendinosis. J Am Podiatr Med Assoc. 2017;107(1):11-16. doi:10.7547/14-146.

166. Welsh RP, Clodman J. Clinical survey of Achilles tendinitis in athletes. Can Med Assoc J. 1980;122(2):193-195.

167. Xu H, Li H, Hua Y, et al. Chinese consensus on insertional Achilles tendinopathy. Orthop J Sports Med. 2019;7(10):N.PAG-N.PAG. doi:10.1177/2325967119879052.

168. Zellers JA, Bley BC, Pohlig RT, Hamdan Alghamdi N, Grävare Silbernagel K. Frequency of pathology on diagnostic ultrasound and relationship to patient demographics in individuals with insertional Achilles tendinopathy. Int J Sports Phys Ther. 2019;14(5):761-769.

169. Zhang Q, Cai Y, Hua Y, Shi J, Wang Y, Wang Y. Sonoelastography shows that Achilles tendons with insertional tendinopathy are harder than asymptomatic tendons. Knee Surg Sports Traumatol Arthrosc. 2017;25(6):1839-1848. doi:10.1007/s00167-016-4197-8. 
971 170. Zhang S, Li H, Yao W, Hua Y, Li Y. Therapeutic response of extracorporeal shock wave therapy

972

973

974

975

976

977

978

979

980

981

982

983

984

985

986

987

988

989

990

991

992

993

994

995

996

997

998

999

1000 for insertional Achilles tendinopathy between sports-active and nonsports-active patients with 5year follow-up. Orthop J Sports Med. 2020;8(1):2325967119898118. doi:10.1177/2325967119898118.

171. Zhuang Z, Yang Y, Chhantyal K, et al. Central tendon-splitting approach and double row suturing for the treatment of insertional Achilles tendinopathy. Biomed Res Int. 2019:1-10. doi:10.1155/2019/4920647.

172. Romero-Morales C, Martín-Llantino PJ, Calvo-Lobo C, et al. Comparison of the sonographic features of the Achilles Tendon complex in patients with and without achilles tendinopathy: A case-control study. Phys Ther Sport. 2019;35:122-126.

173. Coombes BK, Bisset L, Vicenzino B. Management of lateral elbow tendinopathy: one size does not fit all. J Orthop Sports Phys Ther. 2015;45(11):938-949. doi:10.2519/jospt.2015.5841.

174. Lewis J. Rotator cuff related shoulder pain: assessment, management and uncertainties. Man Ther. 2016;23:57-68. doi:10.1016/j.math.2016.03.009.

175. Lewis J, McCreesh K, Roy J-S, Ginn K. Rotator cuff tendinopathy: navigating the diagnosismanagement conundrum. J Orthop Sports Phys Ther. 2015;45(11):923-937. doi:10.2519/jospt.2015.5941.

176. Maffulli N, Khan KM, Puddu G. Overuse tendon conditions: time to change a confusing terminology. Arthroscopy. 1998;14(8):840-843.

177. Malliaras P, Cook J, Purdam C, Rio E. Patellar tendinopathy: clinical diagnosis, load management, and advice for challenging case presentations. J Orthop Sports Phys Ther. 2015;45(11):887-898. doi:10.2519/jospt.2015.5987.

178. Scott A, Docking S, Vicenzino B, et al. Sports and exercise-related tendinopathies: a review of selected topical issues by participants of the second International Scientific Tendinopathy Symposium (ISTS) Vancouver 2012. Br J Sports Med. 2013;47(9):536-544. doi:10.1136/bjsports-2013-092329.

179. Pham MT, Rajić A, Greig JD, Sargeant JM, Papadopoulos A, McEwen SA. A scoping review of scoping reviews: advancing the approach and enhancing the consistency. Research Synthesis Methods. 2014;5(4):371-385. doi:https://doi.org/10.1002/jrsm.1123. 


\section{Table $\mathbf{1}$ (on next page)}

The nine core health domains of tendinopathy as recommended by Vicenzo et al. $(2020)^{9}$

VAS, Visual Analogue Scale; NRS, numerical rating scale; PCS, Pain Catastrophisation Scale; VISA, Victorian Institute of Sport Assessment; EQ-5D, EuroQol-5 Dimension 
1 Table 1: The nine core health domains of tendinopathy as recommended by Vicenzo et al.

$2 \quad(2020)^{9}$

\begin{tabular}{|c|c|c|}
\hline Domain & Description & Example \\
\hline $\begin{array}{l}\text { Patient rating of overall } \\
\text { condition }\end{array}$ & A single assessment numerical evaluation & $0 \%$ to $100 \%$ \\
\hline $\begin{array}{l}\text { Pain on activity or } \\
\text { loading }\end{array}$ & $\begin{array}{l}\text { Patient reported intensity of pain during a } \\
\text { tendon loading activity. }\end{array}$ & VAS, NRS \\
\hline Participation & $\begin{array}{l}\text { Patient rating of participation levels in sport or } \\
\text { engagement across other areas. }\end{array}$ & $\begin{array}{l}\text { Tegner Activity } \\
\text { Scale }\end{array}$ \\
\hline Function & $\begin{array}{l}\text { Patient rating of function and not referring to the } \\
\text { intensity of their pain. }\end{array}$ & $\begin{array}{l}\text { Patient Specific } \\
\text { Function Scale }\end{array}$ \\
\hline Psychological factors & $\begin{array}{l}\text { Patient rating of psychological impact (e.g. Pain } \\
\text { self efficacy, kinesiophobia, catastrophisation) }\end{array}$ & PCS \\
\hline Disability & $\begin{array}{l}\text { Scores from a combination of patient rated pain } \\
\text { and disability due to pain in relation to tendon } \\
\text { specific loading activities }\end{array}$ & VISA-A \\
\hline $\begin{array}{l}\text { Physical function } \\
\text { capacity }\end{array}$ & $\begin{array}{l}\text { The quantitative measures of physical tasks such } \\
\text { as number of hops, number of squats and } \\
\text { dynamometry. }\end{array}$ & $\begin{array}{l}\text { Single leg heel } \\
\text { raise }\end{array}$ \\
\hline Quality of life & Patient rating of general wellbeing & EQ-5D \\
\hline $\begin{array}{l}\text { Pain over a specified } \\
\text { time }\end{array}$ & $\begin{array}{l}\text { Patient reported intensity of pain over a } \\
\text { specified time period (e.g. morning, night, } 24 \\
\text { hours). }\end{array}$ & VAS, NRS \\
\hline
\end{tabular}

3 VAS, Visual Analogue Scale; NRS, numerical rating scale; PCS, Pain Catastrophisation Scale;

4 VISA, Victorian Institute of Sport Assessment; EQ-5D, EuroQol-5 Dimension 
Table 2 (on next page)

Electronic database search strategy example 
1 Table 2: Electronic database search strategy example

Database Search Strategy

Results

\begin{tabular}{ll}
\hline PubMed & ("tendineous"[All Fields] OR "tendinopathy"[MeSH Terms] OR \\
& "tendinopathy"[All Fields] OR "tendinitis"[All Fields] OR \\
& "tendons"[MeSH Terms] OR "tendons"[All Fields] OR \\
& "tendinous"[All Fields] OR ("tendinopathy"[MeSH Terms] OR \\
& "tendinopathy"[All Fields] OR "tendinosis"[All Fields]) OR \\
& ("tendinopathy"[MeSH Terms] OR "tendinopathy"[All Fields] OR \\
& "tendinopathies"[All Fields]) OR ("tendinopathy"[MeSH Terms] OR \\
& "tendinopathy"[All Fields] OR "tendonopathy"[All Fields]) OR \\
& ("tendinopathy"[MeSH Terms] OR "tendinopathy"[All Fields] OR \\
& "tendonitis"[All Fields] OR "tendon s"[All Fields] OR "tendonous"[All \\
& Fields] OR "tendons"[MeSH Terms] OR "tendons"[All Fields] OR \\
& "tendon"[All Fields]) OR ("tendinopathy"[MeSH Terms] OR \\
& "tendinopathy"[All Fields] OR "tendonosis"[All Fields])) AND \\
& ("diagnosable"[All Fields] OR "diagnosi"[All Fields] OR \\
"diagnosis"[MeSH Terms] OR "diagnosis"[All Fields] OR \\
"diagnose"[All Fields] OR "diagnosed"[All Fields] OR \\
"diagnoses"[All Fields] OR "diagnosing"[All Fields] OR \\
"diagnosis"[MeSH Subheading]) AND ("achiles"[All Fields] OR \\
"achille"[All Fields] OR "achille s"[All Fields] OR "achilles \\
tendon"[MeSH Terms] OR ("achilles"[All Fields] AND "tendon"[All \\
Fields]) OR "achilles tendon"[All Fields] OR "achilles"[All Fields])
\end{tabular}


Table 3 (on next page)

Characteristics of included studies

$\mathrm{n}$, number; RCT, randomised controlled trial 
1 Table 3: Characteristics of included studies

$\begin{array}{ll}\text { Characteristics } & \begin{array}{l}\text { No. of } \\ \text { Studies }\end{array}\end{array}$

(n)

\begin{tabular}{|c|c|c|}
\hline \multirow{2}{*}{\multicolumn{3}{|c|}{ Year of publication }} \\
\hline & & \\
\hline Before 1990 & 2 & 115,166 \\
\hline $1990-1999$ & 3 & $30,39,61$ \\
\hline $2000-2009$ & 59 & $19-21,23,25-27,33,36,41,45,47,52,62,68,70,73,78-83,86-90,93,94,98,100,102-104,109,111,114,120-123,126,131,133,135-139,142,145-149,151,153,155$ \\
\hline \multirow[t]{2}{*}{$2010-2019$} & 79 & $7,8,17,22,24,28,29,31,32,34,35,37,38,40,42,43,46,48-51,53-60,63,65,67,69,71,72,74-76,84,85,91,92,95,97,99,101,105,106,108,110,112,113,116-$ \\
\hline & & $119,124,125,127,129,132,134,140,141,143,144,152,154,156,161-165,167-169,171,172$ \\
\hline $2020-2021$ & 16 & $2,18,44,64,66,77,96,107,128,130,150,157-160,170$ \\
\hline \multicolumn{3}{|l|}{ Type of publication } \\
\hline Clinical guidelines & 3 & $37,108,156$ \\
\hline Consensus statement & 1 & 167 \\
\hline Systematic reviews & 3 & $8,71,104$ \\
\hline RCT & 20 & $33,34,36,56,64,82,85,103,109,123,126,131,135-138,148,150,153,159$ \\
\hline Cohort studies & 31 & $22,27,40,41,49,55,60,76,79-81,83,102,105,110,112,117,118,121,122,142,147,152,154,163,165,166,168,170,171$ \\
\hline Case control studies & 30 & $7,17,25,38,42,44,46,48,57,63,67,68,75,87,88,94,113,114,116,119,127,130,132-134,139,145,162,169,172$ \\
\hline $\begin{array}{l}\text { Cross-sectional } \\
\text { studies }\end{array}$ & 17 & $18,50,51,53,54,59,84,89,98,107,129,141,143,157,158,160,164$ \\
\hline Narrative reviews & 43 & $2,19-21,23,24,26,29,30,32,39,43,45,47,52,58,61,62,69,70,72,73,77,78,90-93,96,97,99-101,111,115,120,125,140,144,146,149,151,155$ \\
\hline Case reports & 6 & $31,35,74,95,124,161$ \\
\hline Protocols & 5 & $28,65,66,106,128$ \\
\hline \multicolumn{3}{|l|}{ Terminology } \\
\hline Tendon pain & 2 & 114,148 \\
\hline Tendinitis & 3 & $19,122,166$ \\
\hline Tendinosis & 3 & $63,79,165$ \\
\hline Tendinopathy & 144 & $2,7,8,17,18,20-38,40-51,53-60,62,64-78,80-113,116-121,123,124,126-143,145-147,149-163,167-172$ \\
\hline $\begin{array}{l}\text { Combined } \\
\text { terminology }\end{array}$ & 7 & $39,52,61,115,125,144,164$ \\
\hline \multicolumn{3}{|l|}{ Tendinopathy location } \\
\hline Insertional & 21 & $19,30,31,40,42,43,52,70,72,99,105,106,110,136,152,156,165,167,168,170,171$ \\
\hline Midportion & 83 & $\begin{array}{l}\text { 7,8,17,20,21,25,26,34-37,41,47-51,53,55,58,59,63,65,66,71,73,74,76,78,83,85,86,88,90,92-95,98,100-104,108,109,111-114,117,120-124,126,127,129,132,134,135,137-139,141 } \\
147,149,150,153-155,159-161,163,164,172\end{array}$ \\
\hline Both & 35 & $22-24,28,32,39,44-46,54,57,61,62,64,67,69,77,79-82,84,91,96,119,125,128,130,133,140,157,158,162,166,169$ \\
\hline Not specified & 20 & 2,18,27,29,33,38,56,60,68,75,87,89,97,107,115,116,118,131,148,151 \\
\hline
\end{tabular}

2 n, number; RCT, randomised controlled trial 
Table 4 (on next page)

Clinical Guidelines and Consensus Statement

$\mathrm{cm}$, centimetres 
1 Table 4: Clinical Guidelines and Consensus Statement

\begin{tabular}{llll} 
Author & Year & Location & Subjective history \\
\hline Carcia et al. ${ }^{37}$ & 2010 & Midportion & $\begin{array}{l}\text { Location of pain (2-6cm above calcaneal insertion) } \\
\text { Pain with tendon loading } \\
\text { Tendon stiffness }\end{array}$ \\
Thomas et al. ${ }^{156}$ & 2010 & Insertional & $\begin{array}{l}\text { Location of pain (insertion) } \\
\text { Pain with tendon loading } \\
\text { Swelling }\end{array}$ \\
Martin et al. ${ }^{108}$ & 2018 & Midportion & $\begin{array}{l}\text { Location of pain (2-6cm above calcaneal insertion) } \\
\text { Pain with tendon loading } \\
\text { Tendon stiffness }\end{array}$ \\
Xu et al. ${ }^{167}$ & 2019 & Insertional & $\begin{array}{l}\text { Location of pain (insertion) } \\
\text { Pain with tendon loading }\end{array}$
\end{tabular}

\section{Clinical tests}

Pain on palpation

Painful Arc Sign

Royal London Hospital Test

Single-leg heel Raise

Hopping

Pain on palpation

Localised tendon thickening on palpation

Pain on palpation

Painful Arc Sign

Royal London Hospital Test

Pain on palpation

Localised swelling on palpation

Pain with active dorsiflexion

Silverskiold Test 
Table 5 (on next page)

Systematic Reviews

$\mathrm{cm}$, centimetres; $\mathrm{M}$, male; $F$, female 
1 Table 5: Systematic Reviews

\begin{tabular}{|c|c|c|c|c|c|}
\hline Author & Year & Sample size & Location & Subjective history & Clinical tests \\
\hline $\begin{array}{l}\text { Magnussen et } \\
\text { al. }{ }^{104}\end{array}$ & 2009 & $\begin{array}{l}677 \\
(\mathrm{M} / \mathrm{F}= \\
347 / 330)\end{array}$ & Midportion & $\begin{array}{l}\text { Location of pain ( } 2-7 \mathrm{~cm} \text { above calcaneal insertion) } \\
\text { Pain with tendon loading }\end{array}$ & $\begin{array}{l}\text { Pain on palpation } \\
\text { Localised swelling on palpation } \\
\text { Localised tendon thickening on palpation } \\
\text { Pain with passive dorsiflexion } \\
\text { Single-leg heel raise } \\
\text { Hopping }\end{array}$ \\
\hline $\begin{array}{l}\text { Hutchison et } \\
\text { al. }{ }^{71}\end{array}$ & 2011 & $\begin{array}{l}578 \\
(\mathrm{M} / \mathrm{F}=\text { not } \\
\text { specified })\end{array}$ & Midportion & $\begin{array}{l}\text { Location of pain ( } 2-6 \mathrm{~cm} \text { above calcaneal insertion) } \\
\text { Pain with tendon loading } \\
\text { Tendon stiffness }\end{array}$ & $\begin{array}{l}\text { Pain on palpation } \\
\text { Localised swelling on palpation } \\
\text { Localised tendon thickening on palpation } \\
\text { Painful Arc Sign } \\
\text { Royal London Hospital Test } \\
\text { Reduced dorsiflexion } \\
\text { Single-leg heel Raise } \\
\text { Jump test }\end{array}$ \\
\hline Reiman et al. ${ }^{8}$ & 2014 & $\begin{array}{l}31 \\
(\mathrm{M} / \mathrm{F}=27 / 4)\end{array}$ & Midportion & $\begin{array}{l}\text { Location of pain ( } 2-6 \mathrm{~cm} \text { above calcaneal insertion) } \\
\text { Pain with tendon loading } \\
\text { Tendon stiffness }\end{array}$ & $\begin{array}{l}\text { Pain on palpation } \\
\text { Localised swelling on palpation } \\
\text { Localised tendon thickening on palpation } \\
\text { Painful Arc Sign } \\
\text { Royal London Hospital Test } \\
\text { Pain with dorsiflexion } \\
\text { Single-leg heel Raise } \\
\text { Hopping }\end{array}$ \\
\hline
\end{tabular}

$2 \mathrm{~cm}$, centimetres; M, male; F, female 
Table 6(on next page)

Randomised Controlled Trials

$\mathrm{cm}$, centimetres; $M$, male; $F$, female 
1 Table 6: Randomised Controlled Trials

\begin{tabular}{|c|c|c|c|c|c|}
\hline Author & Year & Sample size & Location & Subjective history & Clinical tests \\
\hline Mafi et al. ${ }^{103}$ & 2001 & $\begin{array}{l}44 \\
(\mathrm{M} / \mathrm{F}=24 / 20)\end{array}$ & Midportion & $\begin{array}{l}\text { Location of pain ( } 2-6 \mathrm{~cm} \text { above calcaneal insertion) } \\
\text { Duration of symptoms ( }>3 \text { months })\end{array}$ & Pain on palpation \\
\hline $\begin{array}{l}\text { Silbernagel et } \\
\text { al. }{ }^{148}\end{array}$ & 2001 & $\begin{array}{l}49 \\
(\mathrm{M} / \mathrm{F}=36 / 13)\end{array}$ & $\begin{array}{l}\text { Not } \\
\text { specified }\end{array}$ & $\begin{array}{l}\text { Location of pain } \\
\text { Duration of symptoms ( }>3 \text { months) }\end{array}$ & $\begin{array}{l}\text { Pain on palpation } \\
\text { Single leg heel raise } \\
\text { Hopping } \\
\text { Range of motion }\end{array}$ \\
\hline $\begin{array}{l}\text { Paoloni et } \\
\text { al. }{ }^{123}\end{array}$ & 2004 & $\begin{array}{l}65 \\
(\mathrm{M} / \mathrm{F}=40 / 25)\end{array}$ & Midportion & $\begin{array}{l}\text { Location of pain ( } 2-6 \mathrm{~cm} \text { above calcaneal insertion) } \\
\text { Duration of symptoms ( }>3 \text { months) } \\
\text { Gradual onset of pain }\end{array}$ & $\begin{array}{l}\text { Pain on palpation } \\
\text { Localised tendon thickening on palpation } \\
\text { Hopping }\end{array}$ \\
\hline Roos et al. ${ }^{138}$ & 2004 & $\begin{array}{l}44 \\
(\mathrm{M} / \mathrm{F}=21 / 23)\end{array}$ & Midportion & $\begin{array}{l}\text { Location of pain ( } 2-6 \mathrm{~cm} \text { above calcaneal insertion) } \\
\text { Duration of symptoms ( }>4 \text { weeks }) \\
\text { Pain with tendon loading }\end{array}$ & Pain on palpation \\
\hline Bjordal et al. ${ }^{33}$ & 2006 & $\begin{array}{l}7 \\
(\mathrm{M} / \mathrm{F}=\text { not } \\
\text { specified) }\end{array}$ & $\begin{array}{l}\text { Not } \\
\text { specified }\end{array}$ & $\begin{array}{l}\text { Location of pain } \\
\text { Pain with tendon loading }\end{array}$ & $\begin{array}{l}\text { Pain on palpation } \\
\text { Hopping }\end{array}$ \\
\hline Brown et al. ${ }^{36}$ & 2006 & $\begin{array}{l}26 \\
(\mathrm{M} / \mathrm{F}=17 / 9)\end{array}$ & Midportion & $\begin{array}{l}\text { Location of pain } \\
\text { Duration of symptoms ( }>6 \text { weeks) } \\
\text { Gradual onset of pain } \\
\text { Pain with tendon loading }\end{array}$ & $\begin{array}{l}\text { Pain on palpation } \\
\text { Single-leg heel raise } \\
\text { Hopping }\end{array}$ \\
\hline $\begin{array}{l}\text { Knobloch et } \\
\text { al. }{ }^{82}\end{array}$ & 2007 & $\begin{array}{l}20 \\
(\mathrm{M} / \mathrm{F}=11 / 9)\end{array}$ & $\begin{array}{l}\text { Insertional } \\
\text { Midportion }\end{array}$ & $\begin{array}{l}\text { Location of pain ( } 2-6 \mathrm{~cm} \text { above calcaneal insertion) } \\
\text { Location of pain (insertion) } \\
\text { Pain with tendon loading } \\
\text { Swelling }\end{array}$ & Not specified \\
\hline Mayer et al. ${ }^{109}$ & 2007 & $\begin{array}{l}31 \\
(\mathrm{M} / \mathrm{F}=31 / 0)\end{array}$ & Midportion & $\begin{array}{l}\text { Location of pain } \\
\text { Duration of symptoms (>6 months) } \\
\text { Pain with tendon loading }\end{array}$ & $\begin{array}{l}\text { Pain on palpation } \\
\text { Localised tendon thickening on palpation }\end{array}$ \\
\hline
\end{tabular}




\begin{tabular}{|c|c|c|c|c|c|}
\hline $\begin{array}{l}\text { Petersen et } \\
\text { al. }{ }^{26}\end{array}$ & 2007 & $\begin{array}{l}100 \\
(\mathrm{M} / \mathrm{F}=60 / 40)\end{array}$ & Midportion & $\begin{array}{l}\text { Location of pain ( } 2-6 \mathrm{~cm} \text { above calcaneal insertion) } \\
\text { Duration of symptoms ( }>3 \text { months) } \\
\text { Gradual onset of pain } \\
\text { Pain with tendon loading }\end{array}$ & $\begin{array}{l}\text { Pain on palpation } \\
\text { Localised tendon thickening on palpation }\end{array}$ \\
\hline $\begin{array}{l}\text { Rompe et } \\
\text { al. }{ }^{137}\end{array}$ & 2007 & $\begin{array}{l}75 \\
(\mathrm{M} / \mathrm{F}=29 / 46)\end{array}$ & Midportion & $\begin{array}{l}\text { Location of pain ( } 2-6 \mathrm{~cm} \text { above calcaneal insertion) } \\
\text { Duration of symptoms ( }>6 \text { months) } \\
\text { Pain with tendon loading } \\
\text { Swelling }\end{array}$ & Not specified \\
\hline $\begin{array}{l}\text { Rasmussen et } \\
\text { al. }{ }^{131}\end{array}$ & 2008 & $\begin{array}{l}48 \\
(\mathrm{M} / \mathrm{F}=28 / 20)\end{array}$ & $\begin{array}{l}\text { Not } \\
\text { specified }\end{array}$ & $\begin{array}{l}\text { Location of pain } \\
\text { Duration of symptoms ( }>3 \text { months })\end{array}$ & $\begin{array}{l}\text { Pain on palpation } \\
\text { Localised swelling on palpation } \\
\text { Pain with dorsiflexion }\end{array}$ \\
\hline $\begin{array}{l}\text { Rompe et } \\
\text { al. }{ }^{136}\end{array}$ & 2008 & $\begin{array}{l}50 \\
(\mathrm{M} / \mathrm{F}=20 / 30)\end{array}$ & Insertional & $\begin{array}{l}\text { Location of pain } \\
\text { Pain with tendon loading } \\
\text { Duration of symptoms ( }>6 \text { months })\end{array}$ & $\begin{array}{l}\text { Pain on palpation } \\
\text { Painful Arc Sign } \\
\text { Royal London Hospital Test }\end{array}$ \\
\hline $\begin{array}{l}\text { Stergioulas et } \\
\text { al. }{ }^{153}\end{array}$ & 2008 & $\begin{array}{l}40 \\
(\mathrm{M} / \mathrm{F}=25 / 15)\end{array}$ & Midportion & $\begin{array}{l}\text { Location of pain ( } 2-6 \mathrm{~cm} \text { above calcaneal insertion) } \\
\text { Duration of symptoms ( }>6 \text { months) } \\
\text { Pain with tendon loading }\end{array}$ & $\begin{array}{l}\text { Pain on palpation } \\
\text { Reduced active dorsiflexion }\end{array}$ \\
\hline $\begin{array}{l}\text { Rompe et } \\
\text { al. }{ }^{135}\end{array}$ & 2009 & $\begin{array}{l}68 \\
(\mathrm{M} / \mathrm{F}=30 / 38)\end{array}$ & Midportion & $\begin{array}{l}\text { Location of pain ( } 2-6 \mathrm{~cm} \text { above calcaneal insertion) } \\
\text { Duration of symptoms ( }>6 \text { months) } \\
\text { Pain with tendon loading } \\
\text { Swelling }\end{array}$ & Not specified \\
\hline Krogh et al. ${ }^{85}$ & 2016 & $\begin{array}{l}24 \\
(\mathrm{M} / \mathrm{F}=13 / 11)\end{array}$ & Midportion & $\begin{array}{l}\text { Location of pain }(2-7 \mathrm{~cm} \text { above calcaneal insertion) } \\
\text { Pain with tendon loading }\end{array}$ & $\begin{array}{l}\text { Pain on palpation } \\
\text { Localised tendon thickening on palpation }\end{array}$ \\
\hline Boesen et al. ${ }^{34}$ & 2017 & $\begin{array}{l}60 \\
(\mathrm{M} / \mathrm{F}=60 / 0)\end{array}$ & Midportion & $\begin{array}{l}\text { Location of pain }(2-7 \mathrm{~cm} \text { above calcaneal insertion) } \\
\text { Duration of symptoms ( }>3 \text { months })\end{array}$ & $\begin{array}{l}\text { Pain on palpation } \\
\text { Localised tendon thickening on palpation } \\
\text { Single-leg heel raise }\end{array}$ \\
\hline $\begin{array}{l}\text { Ebbesen et } \\
\text { al. }{ }^{56}\end{array}$ & 2018 & $\begin{array}{l}44 \\
(\mathrm{M} / \mathrm{F}=25 / 19)\end{array}$ & $\begin{array}{l}\text { Not } \\
\text { specified }\end{array}$ & $\begin{array}{l}\text { Location of pain } \\
\text { Duration of symptoms ( }>3 \text { months) }\end{array}$ & Not specified \\
\hline Gatz et al. ${ }^{64}$ & 2020 & $\begin{array}{l}42 \\
(\mathrm{M} / \mathrm{F}=20 / 22)\end{array}$ & $\begin{array}{l}\text { Insertional } \\
\text { Midportion }\end{array}$ & $\begin{array}{l}\text { Pain with tendon loading } \\
\text { Duration of symptoms ( }>2 \text { months) } \\
\text { Tendon stiffness }\end{array}$ & Pain on palpation \\
\hline
\end{tabular}




$\begin{array}{lllll}\begin{array}{l}\text { Solomons et } \\ \text { al. }{ }^{150}\end{array} & 52020 & \text { Midportion } & \text { Location of pain } & \text { Double leg heel raise } \\ & (\mathrm{M} / \mathrm{F}=24 / 28) & & \text { Duration of symptoms }(>3 \text { months }) & \begin{array}{l}\text { Single leg heel raise } \\ \text { Jump }\end{array} \\ & & \text { Pain with tendon loading } & \text { Hopping }\end{array}$
Van Der Vlist 2020
91
$(\mathrm{M} / \mathrm{F}=45 / 46)$
Midportion
Location of pain $(2-7 \mathrm{~cm}$ above calcaneal insertion)
Duration of symptoms ( $>2$ months)
Pain on palpation
Localised swelling on palpation

2 cm, centimetres; M, male; F, female 
Table 7 (on next page)

Cohort Studies

$\mathrm{cm}$, centimetres; M, male; F, female; VISA-A, Victorian Institute of Sport Assessment-Achilles 
1 Table 7: Cohort Studies

\begin{tabular}{|c|c|c|c|c|c|c|}
\hline Author & Year & Study design & Sample size & Location & Subjective history & Clinical tests \\
\hline $\begin{array}{l}\text { Welsh and } \\
\text { Clodman }\end{array}$ & 1980 & Retrospective & $\begin{array}{l}50 \\
(\mathrm{M} / \mathrm{F}=28 / 22)\end{array}$ & $\begin{array}{l}\text { Insertional } \\
\text { Midportion }\end{array}$ & $\begin{array}{l}\text { Location of pain ( } 2-4 \mathrm{~cm} \text { above calcaneal insertion) } \\
\text { Pain with tendon loading }\end{array}$ & Pain on palpation \\
\hline $\begin{array}{l}\text { Karjalainen et } \\
\text { al. }{ }^{79}\end{array}$ & 2000 & Prospective & $\begin{array}{l}100 \\
(\mathrm{M} / \mathrm{F}=75 / 25)\end{array}$ & $\begin{array}{l}\text { Insertional } \\
\text { Midportion }\end{array}$ & $\begin{array}{l}\text { Location of pain } \\
\text { Duration of symptoms (not specified) }\end{array}$ & $\begin{array}{l}\text { Pain on palpation } \\
\text { Localised tendon } \\
\text { thickening on } \\
\text { palpation }\end{array}$ \\
\hline $\begin{array}{l}\text { Paavola et } \\
\text { al. }{ }^{122}\end{array}$ & 2000 & Prospective & $\begin{array}{l}107 \\
(\mathrm{M} / \mathrm{F}=78 / 29)\end{array}$ & Midportion & $\begin{array}{l}\text { Pain with tendon loading } \\
\text { Duration of symptoms ( }<6 \text { months) }\end{array}$ & $\begin{array}{l}\text { Pain on palpation } \\
\text { Range of motion } \\
\text { Single-leg heel } \\
\text { raise } \\
\text { Single-leg stance }\end{array}$ \\
\hline $\begin{array}{l}\text { Paavola et } \\
\text { al. }{ }^{121}\end{array}$ & 2002 & Prospective & $\begin{array}{l}42 \\
(\mathrm{M} / \mathrm{F}=29 / 13)\end{array}$ & Midportion & Pain with tendon loading & $\begin{array}{l}\text { Pain on palpation } \\
\text { Localised tendon } \\
\text { thickening on } \\
\text { palpation } \\
\text { Localised swelling } \\
\text { on palpation } \\
\text { Range of Motion } \\
\text { Single-leg heel } \\
\text { raise }\end{array}$ \\
\hline Khan et al. ${ }^{80}$ & 2003 & Prospective & $\begin{array}{l}45 \\
(\mathrm{M} / \mathrm{F}=27 / 18)\end{array}$ & $\begin{array}{l}\text { Insertional } \\
\text { Midportion }\end{array}$ & $\begin{array}{l}\text { Pain with tendon loading } \\
\text { Tendon stiffness } \\
\text { VISA-A }\end{array}$ & Pain on palpation \\
\hline $\begin{array}{l}\text { Lakshmanan } \\
\text { and } \\
\text { O’Doherty }^{86}\end{array}$ & 2004 & Prospective & $\begin{array}{l}15 \\
(\mathrm{M} / \mathrm{F}=12 / 3)\end{array}$ & Midportion & $\begin{array}{l}\text { Location of pain } \\
\text { Duration of symptoms ( }>6 \text { months) }\end{array}$ & Not specified \\
\hline Knobloch $^{81}$ & 2007 & Prospective & $\begin{array}{l}64 \\
(\mathrm{M} / \mathrm{F}=39 / 25)\end{array}$ & $\begin{array}{l}\text { Insertional } \\
\text { Midportion }\end{array}$ & $\begin{array}{l}\text { Location of pain ( } 2-6 \mathrm{~cm} \text { above calcaneal insertion)- } \\
\text { midportion } \\
\text { Location of pain (insertion) } \\
\text { Pain with tendon loading } \\
\text { Swelling }\end{array}$ & Not specified \\
\hline
\end{tabular}




\begin{tabular}{|c|c|c|c|c|c|c|}
\hline $\begin{array}{l}\text { Sayana and } \\
\text { Maffulli }^{142}\end{array}$ & 2007 & Prospective & $\begin{array}{l}34 \\
(\mathrm{M} / \mathrm{F}=18 / 16)\end{array}$ & Midportion & $\begin{array}{l}\text { Location of pain ( } 2-6 \mathrm{~cm} \text { above calcaneal insertion) } \\
\text { Pain with tendon loading }\end{array}$ & $\begin{array}{l}\text { Pain on palpation } \\
\text { Painful Arc Sign } \\
\text { Royal London } \\
\text { Hospital Test }\end{array}$ \\
\hline $\begin{array}{l}\text { Silbernagel et } \\
\text { al. }{ }^{147}\end{array}$ & 2007 & Prospective & $\begin{array}{l}37 \\
(\mathrm{M} / \mathrm{F}=20 / 17)\end{array}$ & Midportion & $\begin{array}{l}\text { Location of pain } \\
\text { Duration of symptoms ( }>2 \text { months) } \\
\text { Pain with tendon loading } \\
\text { Swelling }\end{array}$ & $\begin{array}{l}\text { Counter } \\
\text { movement Jump } \\
\text { Hopping } \\
\text { Heel raise }\end{array}$ \\
\hline $\begin{array}{l}\text { Barge- } \\
\text { Caballero et } \\
\text { al. }{ }^{27}\end{array}$ & 2008 & Retrospective & $\begin{array}{l}242 \\
(\mathrm{M} / \mathrm{F}=191 / 51)\end{array}$ & $\begin{array}{l}\text { Not } \\
\text { specified }\end{array}$ & Pain with tendon loading & Pain on palpation \\
\hline Chester et al. ${ }^{41}$ & 2008 & Prospective & $\begin{array}{l}16 \\
(\mathrm{M} / \mathrm{F}=11 / 5)\end{array}$ & Midportion & $\begin{array}{l}\text { Location of pain ( } 2-6 \mathrm{~cm} \text { above calcaneal insertion) } \\
\text { Duration of symptoms ( }>3 \text { months })\end{array}$ & $\begin{array}{l}\text { Pain on palpation } \\
\text { Localised swelling } \\
\text { on palpation }\end{array}$ \\
\hline $\begin{array}{l}\text { Knobloch et } \\
\text { al. }{ }^{83}\end{array}$ & 2008 & Prospective & $\begin{array}{l}121 \\
(\mathrm{M} / \mathrm{F}=74 / 47)\end{array}$ & Midportion & $\begin{array}{l}\text { Location of pain ( } 2-6 \mathrm{~cm} \text { above calcaneal insertion) } \\
\text { Duration of symptoms ( }>3 \text { months })\end{array}$ & $\begin{array}{l}\text { Pain on palpation } \\
\text { Localised swelling } \\
\text { on palpation }\end{array}$ \\
\hline $\begin{array}{l}\text { Maffulli et } \\
\text { al. }{ }^{102}\end{array}$ & 2008 & Prospective & $\begin{array}{l}45 \\
(\mathrm{M} / \mathrm{F}=29 / 16)\end{array}$ & Midportion & $\begin{array}{l}\text { Location of pain ( } 2-6 \mathrm{~cm} \text { above calcaneal insertion) } \\
\text { Pain with tendon loading }\end{array}$ & $\begin{array}{l}\text { Pain on palpation } \\
\text { Painful Arc Sign } \\
\text { Royal London } \\
\text { Hospital Test }\end{array}$ \\
\hline Duthon et al. ${ }^{55}$ & 2011 & Prospective & $\begin{array}{l}14 \\
(\mathrm{M} / \mathrm{F}=11 / 3)\end{array}$ & Midportion & $\begin{array}{l}\text { Location of pain } \\
\text { Duration of symptoms ( }>1 \text { year) }\end{array}$ & $\begin{array}{l}\text { Localised tendon } \\
\text { thickening on } \\
\text { palpation } \\
\text { Range of Motion } \\
\text { Plantarflexion } \\
\text { strength } \\
\text { Silfverskiold test }\end{array}$ \\
\hline Crill et al. ${ }^{49}$ & 2014 & Prospective & $\begin{array}{l}25 \\
(\mathrm{M} / \mathrm{F}=\text { not } \\
\text { specified })\end{array}$ & Midportion & Location of pain ( $2-4 \mathrm{~cm}$ above calcaneal insertion) & $\begin{array}{l}\text { Pain on palpation } \\
\text { Localised tendon } \\
\text { thickening on } \\
\text { palpation } \\
\text { Single-leg heel } \\
\text { raise }\end{array}$ \\
\hline
\end{tabular}




\begin{tabular}{|c|c|c|c|c|c|}
\hline $\begin{array}{l}\text { Murawski et } \\
\text { al. }{ }^{112}\end{array}$ & 2014 & Retrospective & $\begin{array}{l}32 \\
(\mathrm{M} / \mathrm{F}=21 / 11)\end{array}$ & Midportion & $\begin{array}{l}\text { Location of pain ( } 2-7 \mathrm{~cm} \text { above calcaneal insertion) } \\
\text { Pain with tendon loading } \\
\text { Tendon Stiffness }\end{array}$ \\
\hline $\begin{array}{l}\text { McCormack et } \\
\text { al. }{ }^{110}\end{array}$ & 2015 & Prospective & $\begin{array}{l}15 \\
(\mathrm{M} / \mathrm{F}=4 / 11)\end{array}$ & Insertional & $\begin{array}{l}\text { Location of pain (distal } 2 \mathrm{~cm}) \\
\text { Duration of symptoms }(>6 \text { weeks) } \\
\text { Pain with tendon loading } \\
\text { VISA-A }\end{array}$ \\
\hline Oloff et al. ${ }^{118}$ & 2015 & Prospective & $\begin{array}{l}26 \\
(\mathrm{M} / \mathrm{F}=\text { not } \\
\text { specified })\end{array}$ & $\begin{array}{l}\text { Not } \\
\text { specified }\end{array}$ & $\begin{array}{l}\text { Location of pain } \\
\text { Duration of symptoms ( }>6 \text { months) }\end{array}$ \\
\hline Cheng et al. ${ }^{40}$ & 2016 & Prospective & $\begin{array}{l}42 \\
(\mathrm{M} / \mathrm{F}=29 / 13)\end{array}$ & Insertional & $\begin{array}{l}\text { Location of pain (distal } 2 \mathrm{~cm}) \\
\text { Duration of symptoms ( }>6 \text { months) } \\
\text { Swelling } \\
\text { Pain with tendon loading }\end{array}$ \\
\hline $\begin{array}{l}\text { Syvertson et } \\
\text { al. }{ }^{154}\end{array}$ & 2017 & Prospective & $\begin{array}{l}11 \\
(\mathrm{M} / \mathrm{F}=4 / 7)\end{array}$ & Midportion & $\begin{array}{l}\text { Location of pain ( } 2-6 \mathrm{~cm} \text { above calcaneal insertion) } \\
\text { Pain with tendon loading } \\
\text { Tendon stiffness }\end{array}$ \\
\hline Wei et al. ${ }^{165}$ & 2017 & Retrospective & $\begin{array}{l}68 \\
(\mathrm{M} / \mathrm{F}=53 / 15)\end{array}$ & Insertional & $\begin{array}{l}\text { Location of pain } \\
\text { Duration of symptoms ( }>6 \text { months) } \\
\text { Pain with tendon loading }\end{array}$ \\
\hline $\begin{array}{l}\text { Alfredson and } \\
\text { Spang } 22\end{array}$ & 2018 & Retrospective & $\begin{array}{l}771 \\
(\mathrm{M} / \mathrm{F}=481 / 290)\end{array}$ & $\begin{array}{l}\text { Insertional } \\
\text { Midportion }\end{array}$ & $\begin{array}{l}\text { Pain with tendon loading } \\
\text { VISA-A }\end{array}$ \\
\hline Jowett et al. ${ }^{76}$ & 2018 & Prospective & $\begin{array}{l}26 \\
(\mathrm{M} / \mathrm{F}=13 / 13)\end{array}$ & Midportion & $\begin{array}{l}\text { Location of pain } \\
\text { Localised swelling } \\
\text { Duration of symptoms ( }>6 \text { months) }\end{array}$ \\
\hline $\begin{array}{l}\text { Stenson et } \\
\text { al. }{ }^{152}\end{array}$ & 2018 & Retrospective & $\begin{array}{l}664 \\
(\mathrm{M} / \mathrm{F}=312 / 352)\end{array}$ & Insertional & $\begin{array}{l}\text { Location of pain (insertion) } \\
\text { Duration of symptoms ( }>3 \text { months) }\end{array}$ \\
\hline Florit et al. ${ }^{60}$ & 2019 & Retrospective & $\begin{array}{l}110 \\
(\mathrm{M} / \mathrm{F}=103 / 7)\end{array}$ & $\begin{array}{l}\text { Not } \\
\text { specified }\end{array}$ & $\begin{array}{l}\text { Location of pain } \\
\text { Pain with tendon loading }\end{array}$ \\
\hline
\end{tabular}

Pain on palpation Localised tendon thickening on palpation Pain on palpation

Not specified

Not specified

Pain on palpation

Pain on palpation

Not specified

Pain on palpation Localised tendon thickening on palpation

Range of motion

Pain on palpation Pain with tendon loading tests (not specified) 


\begin{tabular}{|c|c|c|c|c|c|c|}
\hline $\begin{array}{l}\text { Mansur et } \\
\text { al. }{ }^{105}\end{array}$ & 2019 & Prospective & $\begin{array}{l}19 \\
(\mathrm{M} / \mathrm{F}=11 / 8)\end{array}$ & Insertional & Location of pain (distal 2cm) & Pain on palpation \\
\hline $\begin{array}{l}\text { O'Neill et } \\
\text { al. }{ }^{117}\end{array}$ & 2019 & Prospective & $\begin{array}{l}16 \\
(\mathrm{M} / \mathrm{F}=11 / 5)\end{array}$ & Midportion & $\begin{array}{l}\text { Location of pain } \\
\text { Duration of symptoms ( }>3 \text { months) } \\
\text { Pain with tendon loading }\end{array}$ & $\begin{array}{l}\text { Pain on palpation } \\
\text { Painful Arc Sign } \\
\text { Royal London } \\
\text { Hospital Test }\end{array}$ \\
\hline $\begin{array}{l}\text { Von Wehren } \\
\text { et al. }{ }^{163}\end{array}$ & 2019 & Retrospective & $\begin{array}{l}50 \\
(\mathrm{M} / \mathrm{F}=27 / 23)\end{array}$ & Midportion & $\begin{array}{l}\text { Location of pain } \\
\text { Duration of symptoms ( }>6 \text { weeks) } \\
\text { Pain with tendon loading }\end{array}$ & $\begin{array}{l}\text { Pain on palpation } \\
\text { Localised swelling } \\
\text { on palpation }\end{array}$ \\
\hline Zellers et al. ${ }^{168}$ & 2019 & Retrospective & $\begin{array}{l}56 \\
(\mathrm{M} / \mathrm{F}=25 / 31)\end{array}$ & Insertional & Location of pain (insertion) & Pain on palpation \\
\hline $\begin{array}{l}\text { Zhuang et } \\
\text { al. }{ }^{171}\end{array}$ & 2019 & Prospective & $\begin{array}{l}28 \\
(\mathrm{M} / \mathrm{F}=17 / 11)\end{array}$ & Insertional & Location of pain (insertion) & $\begin{array}{l}\text { Pain on palpation } \\
\text { Localised tendon } \\
\text { thickening on } \\
\text { palpation } \\
\text { Pain with resisted } \\
\text { plantarflexion } \\
\text { Reduced } \\
\text { plantarflexion } \\
\text { strength } \\
\text { Heel raise test }\end{array}$ \\
\hline Zhang ${ }^{170}$ & 2020 & Retrospective & $\begin{array}{l}33 \\
(\mathrm{M} / \mathrm{F}=31 / 2)\end{array}$ & Insertional & $\begin{array}{l}\text { Location of pain (insertion) } \\
\text { Duration of symptoms ( }>3 \text { months) }\end{array}$ & Not specified \\
\hline
\end{tabular}

2 cm, centimetres; M, male; F, female; VISA-A, Victorian Institute of Sport Assessment-Achilles 
Table 8(on next page)

Case-control studies

$\mathrm{cm}$, centimetres; M, male; F, female; VISA-A, Victorian Institute of Sport Assessment-Achilles 
1 Table 8: Case-control studies

\begin{tabular}{|c|c|c|c|c|c|}
\hline Author & Year & Sample size & Location & Subjective history & Clinical tests \\
\hline $\begin{array}{l}\text { Maffulli et } \\
\text { al. }{ }^{94}\end{array}$ & 2003 & $\begin{array}{l}24 \\
(\mathrm{M} / \mathrm{F}=24 / 0)\end{array}$ & Midportion & Not specified & $\begin{array}{l}\text { Pain on palpation } \\
\text { Painful Arc Sign } \\
\text { Royal London Hospital Test }\end{array}$ \\
\hline $\begin{array}{l}\text { Neeter et } \\
\text { al. }{ }^{114}\end{array}$ & 2003 & $\begin{array}{l}25 \\
(\mathrm{M} / \mathrm{F}=15 / 10)\end{array}$ & Midportion & $\begin{array}{l}\text { Location of pain }(2-6 \mathrm{~cm} \text { above calcaneal } \\
\text { insertion) } \\
\text { Duration of symptoms ( }<3 \text { months })\end{array}$ & $\begin{array}{l}\text { Pain on palpation } \\
\text { Range of motion } \\
\text { Single-leg heel raise }\end{array}$ \\
\hline $\begin{array}{l}\text { Reiter et } \\
\text { al. }{ }^{133}\end{array}$ & 2004 & $\begin{array}{l}35 \\
(\mathrm{M} / \mathrm{F}=30 / 5)\end{array}$ & $\begin{array}{l}\text { Insertional } \\
\text { Midportion }\end{array}$ & $\begin{array}{l}\text { Location of pain } \\
\text { Pain with tendon loading } \\
\text { VISA-A }\end{array}$ & $\begin{array}{l}\text { Pain on palpation } \\
\text { Localised tendon thickening on palpation }\end{array}$ \\
\hline $\begin{array}{l}\text { Holmes and } \\
\operatorname{Lin}^{68}\end{array}$ & 2006 & $\begin{array}{l}82 \\
(\mathrm{M} / \mathrm{F}=44 / 38)\end{array}$ & $\begin{array}{l}\text { Not } \\
\text { specified }\end{array}$ & $\begin{array}{l}\text { Location of pain } \\
\text { Pain with tendon loading }\end{array}$ & Pain on palpation \\
\hline $\begin{array}{l}\text { Leung and } \\
\text { Griffith }^{87}\end{array}$ & 2008 & $\begin{array}{l}71 \\
(\mathrm{M} / \mathrm{F}=31 / 40)\end{array}$ & $\begin{array}{l}\text { Not } \\
\text { specified }\end{array}$ & $\begin{array}{l}\text { Location of pain } \\
\text { Duration of symptoms ( }>6 \text { months) }\end{array}$ & $\begin{array}{l}\text { Pain on palpation } \\
\text { Localised thickening on palpation } \\
\text { Localised swelling on palpation }\end{array}$ \\
\hline $\begin{array}{l}\text { Azevedo et } \\
\text { al. }{ }^{25}\end{array}$ & 2009 & $\begin{array}{l}42 \\
(\mathrm{M} / \mathrm{F}=32 / 10)\end{array}$ & Midportion & $\begin{array}{l}\text { Gradual onset of pain } \\
\text { Tendon stiffness } \\
\text { Swelling } \\
\text { Pain with tendon loading }\end{array}$ & $\begin{array}{l}\text { Pain on palpation } \\
\text { Localised tendon thickening on palpation } \\
\text { Painful Arc Sign }\end{array}$ \\
\hline $\begin{array}{l}\text { Lohrer and } \\
\text { Nauck }^{88}\end{array}$ & 2009 & $\begin{array}{l}119 \\
(\mathrm{M} / \mathrm{F}=\text { not } \\
\text { specified })\end{array}$ & Midportion & $\begin{array}{l}\text { Location of pain }(2-7 \mathrm{~cm} \text { above calcaneal } \\
\text { insertion) } \\
\text { Pain with tendon loading }\end{array}$ & Pain on palpation \\
\hline Ryan et al. ${ }^{139}$ & 2009 & $\begin{array}{l}48 \\
(\mathrm{M} / \mathrm{F}=48 / 0)\end{array}$ & Midportion & $\begin{array}{l}\text { Location of pain ( } 2-6 \mathrm{~cm} \text { above calcaneal } \\
\text { insertion) } \\
\text { Duration of symptoms ( }>3 \text { months) } \\
\text { Pain with tendon loading }\end{array}$ & Not specified \\
\hline $\begin{array}{l}\text { Senkerij et } \\
\text { al. }{ }^{145}\end{array}$ & 2009 & $\begin{array}{l}25 \\
(\mathrm{M} / \mathrm{F}=16 / 9)\end{array}$ & Midportion & $\begin{array}{l}\text { Location of pain }(2-7 \mathrm{~cm} \text { above calcaneal } \\
\text { insertion) } \\
\text { Pain with tendon loading }\end{array}$ & Pain on palpation \\
\hline
\end{tabular}




\begin{tabular}{|c|c|c|c|c|c|}
\hline $\begin{array}{l}\text { Verrall et } \\
\text { al. }{ }^{162}\end{array}$ & 2011 & $\begin{array}{l}190 \\
(\mathrm{M} / \mathrm{F}= \\
108 / 82)\end{array}$ & $\begin{array}{l}\text { Insertional } \\
\text { Midportion }\end{array}$ & $\begin{array}{l}\text { Location of pain ( } 2-6 \mathrm{~cm} \text { above calcaneal } \\
\text { insertion) } \\
\text { Location of pain (distal } 2 \mathrm{~cm}) \\
\text { Duration of symptoms ( }>3 \text { months) } \\
\text { Pain with tendon loading } \\
\text { Tendon stiffness }\end{array}$ & $\begin{array}{l}\text { Pain on palpation } \\
\text { Localised swelling on palpation }\end{array}$ \\
\hline Reid et al. ${ }^{132}$ & 2012 & $\begin{array}{l}36 \\
(\mathrm{M} / \mathrm{F}=\text { not } \\
\text { specified })\end{array}$ & Midportion & $\begin{array}{l}\text { Location of pain }(2-6 \mathrm{~cm} \text { above calcaneal } \\
\text { insertion) } \\
\text { Pain with tendon loading }\end{array}$ & Pain on palpation \\
\hline $\begin{array}{l}\text { Hutchison et } \\
\text { al. }{ }^{7}\end{array}$ & 2013 & $\begin{array}{l}21 \\
(\mathrm{M} / \mathrm{F}=9 / 12)\end{array}$ & Midportion & $\begin{array}{l}\text { Location of pain }(2-6 \mathrm{~cm} \text { above calcaneal } \\
\text { insertion) } \\
\text { Tendon stiffness }\end{array}$ & $\begin{array}{l}\text { Pain on palpation } \\
\text { Localised tendon thickening on palpation } \\
\text { Painful Arc Sign } \\
\text { Royal London Hospital Test } \\
\text { Pain with dorsiflexion } \\
\text { Single-leg heel raise } \\
\text { Hopping }\end{array}$ \\
\hline $\begin{array}{l}\text { Pingel et } \\
\text { al. }{ }^{127}\end{array}$ & 2013 & $\begin{array}{l}18 \\
(\mathrm{M} / \mathrm{F}=10 / 8)\end{array}$ & Midportion & $\begin{array}{l}\text { Location of pain } \\
\text { Duration of symptoms ( }>6 \text { months) }\end{array}$ & $\begin{array}{l}\text { Pain on palpation } \\
\text { Localised swelling on palpation }\end{array}$ \\
\hline Ooi et al. ${ }^{119}$ & 2015 & $\begin{array}{l}240 \\
(\mathrm{M} / \mathrm{F}= \\
180 / 60)\end{array}$ & $\begin{array}{l}\text { Insertional } \\
\text { Midportion }\end{array}$ & $\begin{array}{l}\text { Location of pain } \\
\text { Duration of symptoms ( }>3 \text { months) }\end{array}$ & $\begin{array}{l}\text { Pain on palpation } \\
\text { Localised swelling on palpation }\end{array}$ \\
\hline $\begin{array}{l}\text { Chimenti et } \\
\text { al. }{ }^{42}\end{array}$ & 2016 & $\begin{array}{l}40 \\
(\mathrm{M} / \mathrm{F}=20 / 20)\end{array}$ & Insertional & $\begin{array}{l}\text { Location of pain (insertion) } \\
\text { Pain with tendon loading }\end{array}$ & Pain on palpation \\
\hline $\begin{array}{l}\text { Gardin et } \\
\text { al. }{ }^{63}\end{array}$ & 2016 & $\begin{array}{l}30 \\
(\mathrm{M} / \mathrm{F}=12 / 18)\end{array}$ & Midportion & $\begin{array}{l}\text { Location of pain }(2-7 \mathrm{~cm} \text { above calcaneal } \\
\text { insertion) } \\
\text { Duration of symptoms ( }>6 \text { months })\end{array}$ & Pain on palpation \\
\hline $\begin{array}{l}\text { Nadeau et } \\
\text { al. }{ }^{113}\end{array}$ & 2016 & $\begin{array}{l}43 \\
(\mathrm{M} / \mathrm{F}=30 / 13)\end{array}$ & Midportion & $\begin{array}{l}\text { Location of pain (middle third) } \\
\text { Duration of symptoms ( }>4 \text { weeks) } \\
\text { VISA-A }\end{array}$ & $\begin{array}{l}\text { Pain on palpation } \\
\text { Localised tendon thickening on palpation } \\
\text { Pain with passive dorsiflexion } \\
\text { Pain with resisted plantarflexion } \\
\text { Single-leg heel raise } \\
\text { Hopping }\end{array}$ \\
\hline
\end{tabular}




\begin{tabular}{|c|c|c|c|c|c|}
\hline $\begin{array}{l}\text { Creaby et } \\
\text { al. }{ }^{48}\end{array}$ & 2017 & $\begin{array}{l}25 \\
(\mathrm{M} / \mathrm{F}=25 / 0)\end{array}$ & Midportion & $\begin{array}{l}\text { Location of pain } \\
\text { Pain with tendon loading } \\
\text { Tendon stiffness }\end{array}$ & $\begin{array}{l}\text { Pain on palpation } \\
\text { Hopping }\end{array}$ \\
\hline $\begin{array}{l}\text { Jewson et } \\
\text { al. }{ }^{75}\end{array}$ & 2017 & $\begin{array}{l}35 \\
(\mathrm{M} / \mathrm{F}=22 / 13)\end{array}$ & $\begin{array}{l}\text { Not } \\
\text { specified }\end{array}$ & $\begin{array}{l}\text { Location of pain } \\
\text { Duration of symptoms ( }>4 \text { weeks) } \\
\text { Pain with tendon loading }\end{array}$ & Not specified \\
\hline $\begin{array}{l}\text { Zhang et } \\
\text { al. } 169\end{array}$ & 2017 & $\begin{array}{l}37 \\
(\mathrm{M} / \mathrm{F}=26 / 11)\end{array}$ & $\begin{array}{l}\text { Insertional } \\
\text { Midportion }\end{array}$ & $\begin{array}{l}\text { Location of pain ( } 2-6 \mathrm{~cm} \text { above calcaneal } \\
\text { insertion) } \\
\text { Location of pain (insertion) }\end{array}$ & $\begin{array}{l}\text { Pain on palpation } \\
\text { Pain with resisted plantarflexion }\end{array}$ \\
\hline $\begin{array}{l}\text { Cassel et } \\
\text { al. }{ }^{38}\end{array}$ & 2018 & $\begin{array}{l}182 \\
(\mathrm{M} / \mathrm{F}= \\
113 / 69)\end{array}$ & $\begin{array}{l}\text { Not } \\
\text { specified }\end{array}$ & Pain with tendon loading & Pain on palpation \\
\hline $\begin{array}{l}\text { Coombes et } \\
\text { al. }{ }^{46}\end{array}$ & 2018 & $\begin{array}{l}67 \\
(\mathrm{M} / \mathrm{F}=37 / 30)\end{array}$ & $\begin{array}{l}\text { Insertional } \\
\text { Midportion }\end{array}$ & $\begin{array}{l}\text { Location of pain } \\
\text { Duration of symptoms ( }>3 \text { months) }\end{array}$ & $\begin{array}{l}\text { Pain on palpation } \\
\text { Single-leg heel raise }\end{array}$ \\
\hline $\begin{array}{l}\text { Hernandez- } \\
\text { Sanchez et } \\
\text { al. }{ }^{67}\end{array}$ & 2018 & $\begin{array}{l}210 \\
(\mathrm{M} / \mathrm{F}= \\
148 / 62)\end{array}$ & $\begin{array}{l}\text { Insertional } \\
\text { Midportion }\end{array}$ & $\begin{array}{l}\text { Location of pain } \\
\text { Pain with tendon loading } \\
\text { Tendon stiffness }\end{array}$ & Not specified \\
\hline $\begin{array}{l}\text { Nunes de } \\
\text { Mesquita et } \\
\text { al. }{ }^{116}\end{array}$ & 2018 & $\begin{array}{l}67 \\
(\mathrm{M} / \mathrm{F}=41 / 26)\end{array}$ & $\begin{array}{l}\text { Not } \\
\text { specified }\end{array}$ & $\begin{array}{l}\text { Location of pain } \\
\text { Duration of symptoms ( }>2 \text { months) }\end{array}$ & Pain on palpation \\
\hline $\begin{array}{l}\text { Abate and } \\
\text { Salini }{ }^{17}\end{array}$ & 2019 & $\begin{array}{l}64 \\
(\mathrm{M} / \mathrm{F}=40 / 24)\end{array}$ & Midportion & $\begin{array}{l}\text { Location of pain } \\
\text { Pain with tendon loading }\end{array}$ & Pain on palpation \\
\hline $\begin{array}{l}\text { Eckenrode et } \\
\text { al. }{ }^{57}\end{array}$ & 2019 & $\begin{array}{l}41 \\
(\mathrm{M} / \mathrm{F}=19 / 22)\end{array}$ & $\begin{array}{l}\text { Insertional } \\
\text { Midportion }\end{array}$ & $\begin{array}{l}\text { Location of pain } \\
\text { Duration of symptoms ( }>3 \text { months) } \\
\text { Pain with tendon loading }\end{array}$ & $\begin{array}{l}\text { Pain on palpation } \\
\text { Single-leg heel raise }\end{array}$ \\
\hline $\begin{array}{l}\text { Romero- } \\
\text { Morales et } \\
\text { al. }^{134}\end{array}$ & 2019 & $\begin{array}{l}141 \\
(\mathrm{M} / \mathrm{F}= \\
116 / 25)\end{array}$ & Midportion & $\begin{array}{l}\text { Location of pain } \\
\text { Duration of symptoms ( }>3 \text { months) } \\
\text { Pain with tendon loading }\end{array}$ & Pain on palpation \\
\hline $\begin{array}{l}\text { Romero- } \\
\text { Morales et } \\
\text { al. }{ }^{172}\end{array}$ & 2019 & $\begin{array}{l}143(\mathrm{M} / \mathrm{F}= \\
\text { not specified })\end{array}$ & Midportion & $\begin{array}{l}\text { Location of pain } \\
\text { Duration of symptoms ( }>3 \text { months) } \\
\text { Pain with tendon loading }\end{array}$ & Pain on palpation \\
\hline
\end{tabular}




\begin{tabular}{|c|c|c|c|c|c|}
\hline $\begin{array}{l}\text { Chimenti et } \\
\text { al. }{ }^{44}\end{array}$ & 2020 & $\begin{array}{l}46 \\
(\mathrm{M} / \mathrm{F}=30 / 16)\end{array}$ & $\begin{array}{l}\text { Insertional } \\
\text { Midportion }\end{array}$ & $\begin{array}{l}\text { Location of pain ( } 2-6 \mathrm{~cm} \text { above calcaneal } \\
\text { insertion) } \\
\text { Location of pain (distal } 2 \mathrm{~cm}) \\
\text { Duration of symptoms }(>3 \text { months) } \\
\text { Pain with tendon loading } \\
\text { Tendon stiffness }\end{array}$ & Pain on palpation \\
\hline $\begin{array}{l}\text { Rabello et } \\
\text { al. }{ }^{130}\end{array}$ & 2020 & $\begin{array}{l}46 \\
(\mathrm{M} / \mathrm{F}=30 / 16)\end{array}$ & $\begin{array}{l}\text { Insertional } \\
\text { Midportion }\end{array}$ & $\begin{array}{l}\text { Location of pain }(2-6 \mathrm{~cm} \text { above calcaneal } \\
\text { insertion) } \\
\text { Location of pain (distal } 2 \mathrm{~cm})\end{array}$ & Not specified \\
\hline
\end{tabular}

2 cm, centimetres; M, male; F, female; VISA-A, Victorian Institute of Sport Assessment-Achilles 
Table 9 (on next page)

Cross-sectional studies

$\mathrm{cm}$, centimetres; M, male; F, female; VISA-A, Victorian Institute of Sport Assessment-Achilles 
1 Table 9: Cross-sectional studies

\begin{tabular}{|c|c|c|c|c|c|}
\hline Author & Year & Sample size & Location & Subjective history & Clinical tests \\
\hline $\begin{array}{l}\text { Maffulli et } \\
\text { al.98 }\end{array}$ & 2008 & $\begin{array}{l}50 \\
(\mathrm{M} / \mathrm{F}=50 / 0)\end{array}$ & Midportion & $\begin{array}{l}\text { Location of pain ( } 2-6 \mathrm{~cm} \text { above calcaneal insertion) } \\
\text { Duration of symptoms ( }>3 \text { months) } \\
\text { Pain with tendon loading }\end{array}$ & $\begin{array}{l}\text { Pain on palpation } \\
\text { Localised swelling on palpation }\end{array}$ \\
\hline Longo et al. ${ }^{89}$ & 2009 & $\begin{array}{l}178 \\
(\mathrm{M} / \mathrm{F}=110 / 68)\end{array}$ & $\begin{array}{l}\text { Not } \\
\text { specified }\end{array}$ & VISA-A & $\begin{array}{l}\text { Pain on palpation } \\
\text { Localised tendon thickening on palpation } \\
\text { Painful Arc Sign } \\
\text { Royal London Hospital Test }\end{array}$ \\
\hline Divani et al. ${ }^{53}$ & 2010 & $\begin{array}{l}26 \\
(\mathrm{M} / \mathrm{F}=17 / 9)\end{array}$ & Midportion & Not specified & Pain on palpation \\
\hline de Jong et al. ${ }^{\mathbf{5 0}}$ & 2011 & $\begin{array}{l}107 \\
(\mathrm{M} / \mathrm{F}=51 / 56)\end{array}$ & Midportion & Location of pain (above calcaneal insertion) & Not specified \\
\hline Wang et al. ${ }^{164}$ & 2012 & $\begin{array}{l}17 \\
(\mathrm{M} / \mathrm{F}=17 / 0)\end{array}$ & Midportion & $\begin{array}{l}\text { Location of pain ( } 2-6 \mathrm{~cm} \text { above calcaneal insertion) } \\
\text { Duration of symptoms }(>3 \text { months }) \\
\text { Pain with tendon loading } \\
\text { VISA-A }\end{array}$ & $\begin{array}{l}\text { Pain on palpation } \\
\text { Royal London Hospital Test }\end{array}$ \\
\hline $\begin{array}{l}\text { Kragsnaes et } \\
\text { al. }^{84}\end{array}$ & 2014 & $\begin{array}{l}50 \\
(\mathrm{M} / \mathrm{F}=27 / 23)\end{array}$ & $\begin{array}{l}\text { Insertional } \\
\text { Midportion }\end{array}$ & $\begin{array}{l}\text { Location of pain } \\
\text { Duration of symptoms ( }>4 \text { months) }\end{array}$ & Pain on palpation \\
\hline $\begin{array}{l}\text { Docking et } \\
\text { al. } .^{54}\end{array}$ & 2015 & $\begin{array}{l}21 \\
(\mathrm{M} / \mathrm{F}=20 / 1)\end{array}$ & $\begin{array}{l}\text { Insertional } \\
\text { Midportion }\end{array}$ & Pain with tendon loading & $\begin{array}{l}\text { Single-leg heel raise } \\
\text { Hopping }\end{array}$ \\
\hline $\begin{array}{l}\text { De Marchi et } \\
\text { al. }{ }^{51}\end{array}$ & 2018 & $\begin{array}{l}27 \\
(\mathrm{M} / \mathrm{F}=19 / 8)\end{array}$ & Midportion & $\begin{array}{l}\text { Location of pain ( } 2-6 \mathrm{~cm} \text { above calcaneal insertion) } \\
\text { Duration of symptoms }(>6 \text { months) } \\
\text { Pain with tendon loading }\end{array}$ & Not specified \\
\hline Praet et al. ${ }^{129}$ & 2018 & $\begin{array}{l}20 \\
(\mathrm{M} / \mathrm{F}=13 / 7)\end{array}$ & Midportion & $\begin{array}{l}\text { Location of pain ( } 2-6 \mathrm{~cm} \text { above calcaneal insertion) } \\
\text { Duration of symptoms ( }>2 \text { months) }\end{array}$ & Pain on palpation \\
\hline $\begin{array}{l}\text { Scholes et } \\
\text { al. }{ }^{143}\end{array}$ & 2018 & $\begin{array}{l}21 \\
(\mathrm{M} / \mathrm{F}=21 / 0)\end{array}$ & Midportion & $\begin{array}{l}\text { Location of pain (midportion) } \\
\text { Duration of symptoms ( }>3 \text { months) } \\
\text { Pain with tendon loading } \\
\text { Tendon stiffness }\end{array}$ & Not specified \\
\hline
\end{tabular}




\begin{tabular}{|c|c|c|c|c|c|}
\hline $\begin{array}{l}\text { Finnamore et } \\
\text { al. }\end{array}$ & 2019 & $\begin{array}{l}25 \\
(\mathrm{M} / \mathrm{F}=12 / 13)\end{array}$ & Midportion & $\begin{array}{l}\text { Duration of symptoms ( }>3 \text { months) } \\
\text { Pain with tendon loading }\end{array}$ & Pain on palpation \\
\hline $\begin{array}{l}\text { Santamato et } \\
\text { al. }{ }^{\mathbf{1 4 1}}\end{array}$ & 2019 & $12(\mathrm{M} / \mathrm{F}=7 / 5)$ & Midportion & $\begin{array}{l}\text { Location of pain } \\
\text { Duration of symptoms ( }>4 \text { weeks) }\end{array}$ & $\begin{array}{l}\text { Reduced ROM } \\
\text { Pain during AROM } \\
\text { Painful Arc Sign } \\
\text { Royal London Hospital Test }\end{array}$ \\
\hline $\begin{array}{l}\text { Aiyegbusi et } \\
\text { al. }{ }^{\mathbf{1 8}}\end{array}$ & 2020 & $\begin{array}{l}85 \\
(\mathrm{M} / \mathrm{F}=56 / 29)\end{array}$ & $\begin{array}{l}\text { Not } \\
\text { specified }\end{array}$ & VISA-A & Royal London Hospital Test \\
\hline $\begin{array}{l}\text { Mantovani et } \\
\text { al.107 }\end{array}$ & 2020 & $\begin{array}{l}19 \\
(\mathrm{M} / \mathrm{F}=13 / 6)\end{array}$ & $\begin{array}{l}\text { Not } \\
\text { specified }\end{array}$ & $\begin{array}{l}\text { Location of pain } \\
\text { Duration of symptoms ( }>3 \text { months }) \\
\text { VISA-A }(<80)\end{array}$ & Pain on palpation \\
\hline Turner et al. ${ }^{157}$ & 2020 & $\begin{array}{l}15 \\
(\mathrm{M} / \mathrm{F}=8 / 7)\end{array}$ & $\begin{array}{l}\text { Insertional } \\
\text { Midportion }\end{array}$ & $\begin{array}{l}\text { Location of pain } \\
\text { Duration of symptoms ( }>3 \text { months) } \\
\text { Gradual onset of pain } \\
\text { Pain with tendon loading }\end{array}$ & Not specified \\
\hline $\begin{array}{l}\text { Vallance et } \\
\text { al. } \mathbf{1 5 8}\end{array}$ & 2020 & $\begin{array}{l}86 \\
(\mathrm{M} / \mathrm{F}=86 / 0)\end{array}$ & $\begin{array}{l}\text { Insertional } \\
\text { Midportion }\end{array}$ & $\begin{array}{l}\text { Location of pain } \\
\text { Duration of symptoms ( }>3 \text { months) } \\
\text { Pain with tendon loading } \\
\text { Tendon stiffness }\end{array}$ & $\begin{array}{l}\text { Single-leg heel raise } \\
\text { Hopping }\end{array}$ \\
\hline $\begin{array}{l}\text { Van Der Vlist } \\
\text { et al. }{ }^{\mathbf{6 0}}\end{array}$ & 2020 & $\begin{array}{l}28 \\
(\mathrm{M} / \mathrm{F}=16 / 12)\end{array}$ & Midportion & $\begin{array}{l}\text { Location of pain }(2-7 \mathrm{~cm} \text { above calcaneal insertion) } \\
\text { Duration of symptoms ( }>2 \text { months }) \\
\text { Pain with tendon loading }\end{array}$ & $\begin{array}{l}\text { Pain on palpation } \\
\text { Localised swelling on palpation }\end{array}$ \\
\hline
\end{tabular}

cm, centimetres; M, male; F, female; VISA-A, Victorian Institute of Sport Assessment-Achilles 


\section{Table $\mathbf{1 0}$ (on next page)}

Narrative Reviews

cm, centimetres; M, male; F, female; VISA-A, Victorian Institute of Sport Assessment-Achilles;

ROM, range of motion; $m$, metres 
1 Table 10: Narrative Reviews

\begin{tabular}{|c|c|c|c|c|}
\hline Author & Year & Location & Subjective history & Clinical tests \\
\hline Nichols $^{115}$ & 1989 & Not specified & $\begin{array}{l}\text { Location of pain (Distal } 5 \mathrm{~cm} \text { ) } \\
\text { Tendon stiffness } \\
\text { Pain with tendon loading } \\
\text { Gradual onset of pain } \\
\text { Change in activity }\end{array}$ & $\begin{array}{l}\text { Pain on palpation } \\
\text { Localised tendon thickening on palpation } \\
\text { Localised swelling on palpation } \\
\text { Reduced ROM } \\
\text { Hopping }\end{array}$ \\
\hline Fredericson $^{61}$ & 1996 & $\begin{array}{l}\text { Insertional } \\
\text { Midportion }\end{array}$ & $\begin{array}{l}\text { Location of pain ( } 2-6 \mathrm{~cm} \text { above calcaneal insertion) } \\
\text { Location of pain (insertion) } \\
\text { Pain with tendon loading } \\
\text { Tendon stiffness }\end{array}$ & $\begin{array}{l}\text { Pain on palpation } \\
\text { Localised tendon thickening on palpation } \\
\text { Localised swelling on palpation }\end{array}$ \\
\hline $\begin{array}{l}\text { Benazzo et } \\
\text { al. } .^{30}\end{array}$ & 1997 & Insertional & $\begin{array}{l}\text { Pain with tendon loading } \\
\text { Tendon stiffness }\end{array}$ & Pain on palpation \\
\hline Chazan $^{39}$ & 1998 & $\begin{array}{l}\text { Insertional } \\
\text { Midportion }\end{array}$ & $\begin{array}{l}\text { Gradual onset of pain } \\
\text { Tendon stiffness } \\
\text { Pain with tendon loading }\end{array}$ & $\begin{array}{l}\text { Pain on palpation } \\
\text { Localised tendon thickening on palpation } \\
\text { Localised swelling on palpation } \\
\text { Pain with passive dorsiflexion } \\
\text { Pain with resisted plantarflexion } \\
\text { Reduced ROM }\end{array}$ \\
\hline $\begin{array}{l}\text { Jarvinen et } \\
\text { al. }^{73}\end{array}$ & 2001 & Midportion & $\begin{array}{l}\text { Location of pain } \\
\text { Pain with tendon loading }\end{array}$ & $\begin{array}{l}\text { Pain on palpation } \\
\text { Localised swelling on palpation }\end{array}$ \\
\hline Cook et al. ${ }^{45}$ & 2002 & $\begin{array}{l}\text { Insertional } \\
\text { Midportion }\end{array}$ & $\begin{array}{l}\text { Gradual onset of pain } \\
\text { Location of pain } \\
\text { Pain with tendon loading } \\
\text { Tendon stiffness } \\
\text { Change in activity } \\
\text { VISA-A }\end{array}$ & $\begin{array}{l}\text { Pain on palpation } \\
\text { Localised tendon thickening on palpation } \\
\text { Localised swelling on palpation } \\
\text { Single-leg heel raise } \\
\text { Hopping }\end{array}$ \\
\hline Kader et al. ${ }^{78}$ & 2002 & Midportion & $\begin{array}{l}\text { Gradual onset of pain } \\
\text { Location of pain (2-6cm above calcaneal insertion) } \\
\text { Duration of symptoms } \\
\text { Tendon stiffness } \\
\text { Pain with tendon loading }\end{array}$ & $\begin{array}{l}\text { Pain on palpation } \\
\text { Localised tendon thickening on palpation } \\
\text { Painful Arc Sign }\end{array}$ \\
\hline
\end{tabular}




\begin{tabular}{|c|c|c|c|}
\hline $\begin{array}{l}\text { Maffulli and } \\
\text { Kader }^{33}\end{array}$ & 2002 & Midportion & $\begin{array}{l}\text { Gradual onset of pain } \\
\text { Location of pain }(2-6 \mathrm{~cm} \text { above calcaneal insertion) } \\
\text { Duration of symptoms } \\
\text { Pain with tendon loading }\end{array}$ \\
\hline $\begin{array}{l}\text { Paavola et } \\
\text { al. }{ }^{120}\end{array}$ & 2002 & Midportion & $\begin{array}{l}\text { Pain with tendon loading } \\
\text { Duration of symptoms }\end{array}$ \\
\hline Alfredson ${ }^{20}$ & 2003 & Midportion & $\begin{array}{l}\text { Location of pain ( } 2-6 \mathrm{~cm} \text { above calcaneal insertion) } \\
\text { Pain with tendon loading } \\
\text { Tendon stiffness }\end{array}$ \\
\hline Aldridge $^{19}$ & 2004 & Insertional & Pain with tendon loading \\
\hline $\begin{array}{l}\text { Maffulli et } \\
\text { al. }{ }^{100}\end{array}$ & 2004 & Midportion & $\begin{array}{l}\text { Location of pain ( } 2-6 \mathrm{~cm} \text { above calcaneal insertion) } \\
\text { Pain with tendon loading }\end{array}$ \\
\hline $\begin{array}{l}\text { Sorosky et } \\
\text { al. }{ }^{151}\end{array}$ & 2004 & Not specified & $\begin{array}{l}\text { Gradual onset of pain } \\
\text { Pain with tendon loading } \\
\text { Change in training }\end{array}$ \\
\hline Aronow $^{23}$ & 2005 & $\begin{array}{l}\text { Insertional } \\
\text { Midportion }\end{array}$ & Pain with tendon loading \\
\hline $\begin{array}{l}\text { Bains and } \\
\text { Porter }^{26}\end{array}$ & 2006 & Midportion & $\begin{array}{l}\text { Gradual onset of pain } \\
\text { Location of pain }(2-5 \mathrm{~cm} \text { above calcaneal insertion) } \\
\text { Tendon stiffness } \\
\text { Pain with tendon loading } \\
\text { Change in training } \\
\text { VISA-A }\end{array}$ \\
\hline
\end{tabular}

\section{Pain on palpation}

Localised tendon thickening on palpation

Localised swelling on palpation

Painful Arc Sign

\section{Pain on palpation}

Localised tendon thickening on palpation

Localised swelling on palpation

Pain on palpation

Localised swelling on palpation

Pain on palpation

Pain with passive dorsiflexion

Pain on palpation

Localised tendon thickening on palpation

Localised swelling on palpation

\section{Pain on palpation}

Localised tendon thickening on palpation

Localised swelling on palpation

Pain with passive dorsiflexion

Pain with resisted plantarflexion

\section{Pain on palpation}

Localised swelling on palpation

Pain with passive dorsiflexion (insertional)

Painful Arc Sign (midportion)

Single-leg Heel Raise

\section{Pain on palpation}

Localised tendon thickening on palpation

Localised swelling on palpation

Hopping on the spot

Forward hopping

$6 \mathrm{~m}$ hop test 


\begin{tabular}{|c|c|c|c|}
\hline $\begin{array}{l}\text { Sharma and } \\
\text { Maffulli146 }\end{array}$ & 2006 & Midportion & $\begin{array}{l}\text { Location of pain ( } 2-6 \mathrm{~cm} \text { above calcaneal insertion) } \\
\text { Pain with tendon loading } \\
\text { Swelling }\end{array}$ \\
\hline $\begin{array}{l}\text { Alfredson } \\
\text { and Cook }\end{array}$ & 2007 & Midportion & $\begin{array}{l}\text { Pain with tendon loading } \\
\text { Tendon stiffness }\end{array}$ \\
\hline $\begin{array}{l}\text { Furia and } \\
\text { Rompe }\end{array}$ & 2007 & $\begin{array}{l}\text { Insertional } \\
\text { Midportion }\end{array}$ & $\begin{array}{l}\text { Location of pain ( } 2-5 \mathrm{~cm} \text { above calcaneal insertion) - } \\
\text { midportion } \\
\text { Location of pain (insertion) } \\
\text { Pain with tendon loading }\end{array}$ \\
\hline $\begin{array}{l}\text { McShane et } \\
\text { al. }{ }^{111}\end{array}$ & 2007 & Midportion & $\begin{array}{l}\text { Location of pain } \\
\text { Pain with tendon loading } \\
\text { Tendon stiffness }\end{array}$ \\
\hline $\begin{array}{l}\text { Hu and } \\
\text { Flemister }^{70}\end{array}$ & 2008 & Insertional & $\begin{array}{l}\text { Location of pain } \\
\text { Pain with tendon loading } \\
\text { Tendon stiffness }\end{array}$ \\
\hline $\begin{array}{l}\text { Tan and } \\
\text { Chan }^{155}\end{array}$ & 2008 & Midportion & $\begin{array}{l}\text { Location of pain (midportion) } \\
\text { Duration of pain ( }>2 \text { weeks) } \\
\text { Pain with tendon loading } \\
\text { Tendon stiffness }\end{array}$ \\
\hline $\begin{array}{l}\text { Courville et } \\
\text { al. } .^{4}\end{array}$ & 2009 & Midportion & $\begin{array}{l}\text { Pain with tendon loading } \\
\text { Location of pain } \\
\text { Tendon stiffness } \\
\text { Change in activity }\end{array}$ \\
\hline Den Hartog ${ }^{52}$ & 2009 & Insertional & $\begin{array}{l}\text { Gradual onset of pain } \\
\text { Duration of symptoms } \\
\text { Pain with tendon loading }\end{array}$ \\
\hline
\end{tabular}

Pain on palpation

Localised tendon thickening on palpation

Localised swelling on palpation

Localised swelling on palpation

Single-leg Heel Raise

Hopping on the spot

Forward hopping

Pain on palpation

Localised swelling on palpation

Pain with passive dorsiflexion (insertional)

Reduced ROM

Pain on palpation

Localised tendon thickening on palpation

Single-leg heel raise

Pain on palpation

Localised tendon thickening on palpation

Pain with passive dorsiflexion

Reduced ROM

Silfverskiold test

\section{Pain on palpation}

Localised tendon thickening on palpation

Localised swelling on palpation

Single-leg heel raise

Pain on palpation

Localised tendon thickening on palpation

Localised swelling on palpation

\section{Pain on palpation}

Localised tendon thickening on palpation

Localised swelling on palpation 


\begin{tabular}{|c|c|c|c|c|}
\hline Longo $^{90}$ & 2009 & Midportion & $\begin{array}{l}\text { Location of pain ( } 2-6 \mathrm{~cm} \text { above calcaneal insertion) } \\
\text { Pain with tendon loading } \\
\text { Swelling }\end{array}$ & $\begin{array}{l}\text { Pain on palpation } \\
\text { Localised tendon thickening on palpation } \\
\text { Painful Arc Sign } \\
\text { Royal London Hospital Test }\end{array}$ \\
\hline $\begin{array}{l}\text { Simpson and } \\
\text { Howard }{ }^{149}\end{array}$ & 2009 & Midportion & $\begin{array}{l}\text { Location of pain ( } 2-5 \mathrm{~cm} \text { above calcaneal insertion) } \\
\text { Pain with tendon loading } \\
\text { Swelling } \\
\text { Change in activity }\end{array}$ & $\begin{array}{l}\text { Pain on palpation } \\
\text { Localised swelling on palpation } \\
\text { Reduced flexibility in hamstring and calf }\end{array}$ \\
\hline Irwin $^{72}$ & 2010 & Insertional & $\begin{array}{l}\text { Location of pain (calcaneal tuberosity) } \\
\text { Swelling } \\
\text { Pain with tendon loading } \\
\text { Tendon stiffness }\end{array}$ & $\begin{array}{l}\text { Pain on palpation } \\
\text { Localised swelling on palpation }\end{array}$ \\
\hline Scott et al. ${ }^{144}$ & 2011 & MIdportion & $\begin{array}{l}\text { Location of pain } \\
\text { Pain with tendon loading } \\
\text { Swelling }\end{array}$ & $\begin{array}{l}\text { Pain on palpation } \\
\text { Localised tendon thickening on palpation }\end{array}$ \\
\hline $\begin{array}{l}\text { Maffulli et } \\
\text { al. } .^{97}\end{array}$ & 2012 & Midportion & $\begin{array}{l}\text { Location of pain ( } 4-6 \mathrm{~cm} \text { above calcaneal insertion) } \\
\text { Pain with tendon loading } \\
\text { Swelling } \\
\text { Change in activity }\end{array}$ & $\begin{array}{l}\text { Pain on palpation } \\
\text { Localised tendon thickening on palpation } \\
\text { Localised swelling on palpation } \\
\text { Reduced ROM }\end{array}$ \\
\hline $\begin{array}{l}\text { Maffulli et } \\
\text { al. }{ }^{92}\end{array}$ & 2012 & Not specified & $\begin{array}{l}\text { Gradual onset of pain } \\
\text { Tendon stiffness } \\
\text { Pain with tendon loading } \\
\text { Swelling } \\
\text { VISA-A }\end{array}$ & $\begin{array}{l}\text { Pain on palpation } \\
\text { Localised tendon thickening on palpation } \\
\text { Localised swelling on palpation } \\
\text { Painful Arc Sign }\end{array}$ \\
\hline $\begin{array}{l}\text { Asplund and } \\
\text { Best }^{24}\end{array}$ & 2013 & $\begin{array}{l}\text { Insertional } \\
\text { Midportion }\end{array}$ & $\begin{array}{l}\text { Location of pain ( } 2-6 \mathrm{~cm} \text { above calcaneal insertion) } \\
\text { Location of pain (insertion) } \\
\text { Pain with tendon loading } \\
\text { Tendon stiffness }\end{array}$ & $\begin{array}{l}\text { Pain on palpation } \\
\text { Localised swelling on palpation }\end{array}$ \\
\hline $\begin{array}{l}\text { Maffulli et } \\
\text { al. }{ }^{101}\end{array}$ & 2014 & Midportion & $\begin{array}{l}\text { Location of pain ( } 2-6 \mathrm{~cm} \text { above calcaneal insertion) } \\
\text { Pain with tendon loading }\end{array}$ & $\begin{array}{l}\text { Pain on palpation } \\
\text { Localised swelling on palpation } \\
\text { Single-leg heel raise }\end{array}$ \\
\hline
\end{tabular}




\begin{tabular}{|c|c|c|c|}
\hline $\begin{array}{l}\text { Horn and } \\
\text { McCollum }^{69}\end{array}$ & 2015 & $\begin{array}{l}\text { Insertional } \\
\text { Midportion }\end{array}$ & $\begin{array}{l}\text { Location of pain ( } 2-6 \mathrm{~cm} \text { above calcaneal insertion) } \\
\text { Location of pain (insertion) } \\
\text { Pain with tendon loading }\end{array}$ \\
\hline $\begin{array}{l}\text { Maffulli et } \\
\text { al. }{ }^{91}\end{array}$ & 2015 & $\begin{array}{l}\text { Insertional } \\
\text { Midportion }\end{array}$ & $\begin{array}{l}\text { Location of pain ( } 2-6 \mathrm{~cm} \text { above calcaneal insertion) } \\
\text { Location of pain (insertion) } \\
\text { Swelling } \\
\text { Pain with tendon loading }\end{array}$ \\
\hline Saini et al. ${ }^{140}$ & 2015 & $\begin{array}{l}\text { Insertional } \\
\text { Midportion }\end{array}$ & $\begin{array}{l}\text { Location of pain (midportion) } \\
\text { Location of pain (insertion) } \\
\text { Pain with tendon loading }\end{array}$ \\
\hline $\begin{array}{l}\text { Chimenti et } \\
\text { al. }{ }^{43}\end{array}$ & 2017 & Insertional & $\begin{array}{l}\text { Location of pain (distal } 2 \mathrm{~cm} \text { ) } \\
\text { Pain with tendon loading } \\
\text { Tendon stiffness }\end{array}$ \\
\hline Feilmeier $^{58}$ & 2017 & Midportion & $\begin{array}{l}\text { Location of pain ( } 2-6 \mathrm{~cm} \text { above calcaneal insertion) } \\
\text { Swelling } \\
\text { Pain with tendon loading } \\
\text { Tendon stiffness } \\
\text { Change in activity } \\
\text { VISA-A }\end{array}$ \\
\hline $\begin{array}{l}\text { Pedowitz and } \\
\text { Beck }^{125}\end{array}$ & 2017 & $\begin{array}{l}\text { Insertional } \\
\text { Midportion }\end{array}$ & $\begin{array}{l}\text { Location of pain ( } 2-6 \mathrm{~cm} \text { above calcaneal insertion) } \\
\text { Location of pain (insertion) } \\
\text { Pain with tendon loading } \\
\text { Tendon stiffness }\end{array}$ \\
\hline $\begin{array}{l}\text { Baskerville et } \\
\text { al. }{ }^{29}\end{array}$ & 2018 & Not specified & $\begin{array}{l}\text { Gradual onset of pain } \\
\text { Pain with tendon loading } \\
\text { Tendon stiffness }\end{array}$ \\
\hline
\end{tabular}

Localised swelling on palpation

Painful Arc Sign

Royal London Hospital Test

Pain on palpation

Pain on palpation

Localised swelling on palpation

Pain with dorsiflexion and plantarflexion

Pain on palpation

Localised swelling on palpation

Pain with passive dorsiflexion

Pain with resisted plantarflexion

Reduced ROM

\section{Pain on palpation}

Localised tendon thickening on palpation

Pain with passive dorsiflexion

Painful Arc Sign

Royal London Hospital Test

Single-leg Heel Raise

Hopping

Pain on palpation

Single leg heel raise

\section{Pain on palpation}

Pain with passive and active movement

Reduced strength 


\begin{tabular}{|c|c|c|c|c|}
\hline Bhatty et al. ${ }^{32}$ & 2019 & $\begin{array}{l}\text { Insertional } \\
\text { Midportion }\end{array}$ & Pain with tendon loading & $\begin{array}{l}\text { Pain on palpation } \\
\text { Localised swelling on palpation } \\
\text { Pain with passive dorsiflexion (insertional) } \\
\text { Pain with resisted plantarflexion } \\
\text { Reduced ROM }\end{array}$ \\
\hline $\begin{array}{l}\text { Maffulli et } \\
\text { al. }{ }^{99}\end{array}$ & 2019 & Insertional & $\begin{array}{l}\text { Location of pain (distal } 2 \mathrm{~cm} \text { ) } \\
\text { Pain with tendon loading } \\
\text { Tendon stiffness }\end{array}$ & $\begin{array}{l}\text { Pain on palpation } \\
\text { Localised tendon thickening on palpation } \\
\text { Localised swelling on palpation }\end{array}$ \\
\hline Jukes et al. ${ }^{77}$ & 2020 & $\begin{array}{l}\text { Insertional } \\
\text { Midportion }\end{array}$ & $\begin{array}{l}\text { Location of pain } \\
\text { Pain with tendon loading } \\
\text { Tendon stiffness } \\
\text { Duration of symptoms }\end{array}$ & $\begin{array}{l}\text { Pain on palpation } \\
\text { Localised tendon thickening on palpation } \\
\text { Localised swelling on palpation } \\
\text { Royal London Hospital Test } \\
\text { Silfverskiold test }\end{array}$ \\
\hline $\begin{array}{l}\text { Maffulli et } \\
\text { al. }{ }^{96}\end{array}$ & 2020 & $\begin{array}{l}\text { Insertional } \\
\text { Midportion }\end{array}$ & $\begin{array}{l}\text { Location of pain } \\
\text { Pain with tendon loading } \\
\text { Localised swelling } \\
\text { Tendon stiffness }\end{array}$ & $\begin{array}{l}\text { Pain on palpation } \\
\text { Painful Arc Sign } \\
\text { Royal London Hospital Test }\end{array}$ \\
\hline Millar et al. ${ }^{2}$ & 2021 & Not specified & $\begin{array}{l}\text { Location of pain } \\
\text { Pain with tendon loading } \\
\text { Tendon stiffness }\end{array}$ & $\begin{array}{l}\text { Pain on palpation } \\
\text { Painful Arc Sign } \\
\text { Royal London Hospital Test } \\
\text { Single leg heel raise } \\
\text { Hopping }\end{array}$ \\
\hline
\end{tabular}




\section{Table 11(on next page)}

Case reports

$\mathrm{cm}$, centimetres; $M$, male; $F$, female; ROM, range of motion; MMT, manual muscle test 
1 Table 11: Case reports

\begin{tabular}{|c|c|c|c|c|c|}
\hline Author & Year & Sample size & Location & Subjective history & Clinical tests \\
\hline $\begin{array}{l}\text { Maffulli et } \\
\text { al. }{ }^{95}\end{array}$ & 2011 & $1(\mathrm{M} / \mathrm{F}=1 / 0)$ & Midportion & $\begin{array}{l}\text { Location of pain ( } 2-4 \mathrm{~cm} \text { above calcaneal insertion) } \\
\text { Duration of symptoms ( }>3 \text { months) } \\
\text { Pain with tendon loading }\end{array}$ & $\begin{array}{l}\text { Pain on palpation } \\
\text { Painful Arc Sign } \\
\text { Royal London Hospital Test }\end{array}$ \\
\hline $\begin{array}{l}\text { Van } \\
\text { Sterkenburg et } \\
\text { al. }{ }^{161}\end{array}$ & 2011 & $3(\mathrm{M} / \mathrm{F}=1 / 2)$ & Midportion & $\begin{array}{l}\text { Location of pain ( } 4-7 \mathrm{~cm} \text { above calcaneal insertion) } \\
\text { Tendon stiffness }\end{array}$ & Pain on palpation \\
\hline $\mathrm{Papa}^{124}$ & 2012 & $1(\mathrm{M} / \mathrm{F}=0 / 1)$ & Midportion & $\begin{array}{l}\text { Gradual onset of pain } \\
\text { Pain with tendon loading }\end{array}$ & $\begin{array}{l}\text { Pain on palpation } \\
\text { Localised tendon thickening on palpation } \\
\text { Localised swelling on palpation } \\
\text { Reduced ROM } \\
\text { Single-leg heel raise }\end{array}$ \\
\hline Benito $^{31}$ & 2016 & $5(\mathrm{M} / \mathrm{F}=2 / 3)$ & Insertional & $\begin{array}{l}\text { Location of pain (insertion) } \\
\text { Gradual onset of pain } \\
\text { Pain with tendon loading }\end{array}$ & Not specified \\
\hline $\begin{array}{l}\text { Borda and } \\
\text { Selhorst }{ }^{35}\end{array}$ & 2017 & $1(\mathrm{M} / \mathrm{F}=0 / 1)$ & Midportion & $\begin{array}{l}\text { Gradual onset of pain } \\
\text { Pain with tendon loading }\end{array}$ & $\begin{array}{l}\text { Pain on palpation } \\
\text { MMT } \\
\text { Single-leg heel raise }\end{array}$ \\
\hline $\begin{array}{l}\text { Jayaseelan et } \\
\text { al. }{ }^{74}\end{array}$ & 2019 & $2(\mathrm{M} / \mathrm{F}=1 / 1)$ & Midportion & $\begin{array}{l}\text { Location of pain } \\
\text { Pain with tendon loading }\end{array}$ & $\begin{array}{l}\text { Pain on palpation } \\
\text { Single-leg heel raise } \\
\text { Hopping } \\
\text { Reduced ROM }\end{array}$ \\
\hline
\end{tabular}

2 cm, centimetres; M, male; F, female; ROM, range of motion; MMT, manual muscle test 


\section{Table 12 (on next page)}

Protocols

$\mathrm{cm}$, centimetres; VISA-A, Victorian Institute of Sport Assessment-Achilles 
1 Table 12: Protocols

\begin{tabular}{|c|c|c|c|c|}
\hline Author & Year & Location & Subjective history & Clinical tests \\
\hline $\begin{array}{l}\text { Barker-Davies } \\
\text { et al. }{ }^{28}\end{array}$ & 2017 & $\begin{array}{l}\text { Insertional } \\
\text { Midportion }\end{array}$ & $\begin{array}{l}\text { Location of pain (2-6cm above calcaneal insertion) } \\
\text { Location of pain (insertion) } \\
\text { Pain with tendon loading } \\
\text { Tendon stiffness } \\
\text { Change in training }\end{array}$ & $\begin{array}{l}\text { Pain on palpation Single-leg heel raise } \\
\text { Hopping }\end{array}$ \\
\hline Habets et al. ${ }^{65}$ & 2017 & Midportion & $\begin{array}{l}\text { Location of pain }(2-7 \mathrm{~cm} \text { above calcaneal insertion) } \\
\text { Duration of symptoms ( }>3 \text { months) } \\
\text { Pain with tendon loading }\end{array}$ & $\begin{array}{l}\text { Pain on palpation } \\
\text { Localised swelling on palpation }\end{array}$ \\
\hline $\begin{array}{l}\text { Mansur et } \\
\text { al. }{ }^{106}\end{array}$ & 2017 & Insertional & $\begin{array}{l}\text { Location of pain (distal } 2 \mathrm{~cm}) \\
\text { Duration of symptoms (>3 months) }\end{array}$ & Pain on palpation \\
\hline Hasani et al. ${ }^{66}$ & 2020 & Midportion & $\begin{array}{l}\text { Location of pain ( } 2-6 \mathrm{~cm} \text { above calcaneal insertion) } \\
\text { Pain with tendon loading } \\
\text { Tendon stiffness } \\
\text { VISA-A }\end{array}$ & Not specified \\
\hline Post et al. ${ }^{128}$ & 2020 & $\begin{array}{l}\text { Insertional } \\
\text { Midportion }\end{array}$ & $\begin{array}{l}\text { Location of pain } \\
\text { Pain with tendon loading }\end{array}$ & $\begin{array}{l}\text { Walking } \\
\text { Single-leg heel raise } \\
\text { Hopping }\end{array}$ \\
\hline
\end{tabular}

cm, centimetres; VISA-A, Victorian Institute of Sport Assessment-Achilles

Single-leg heel raise 


\section{Table $\mathbf{1 3}$ (on next page)}

A method for clinically diagnosing Achilles tendinopathy

N/A, not applicable; cm, centimetres; VAS, Visual Analogue Scale; NPRS, Numerical Pain Rating Scale; VISA-A, Victorian Institute of Sport Assessment-Achilles; PCS, Pain Catastrophising Scale; SF-12, 12-Item Short Form Survey 
1 Table 13: A method for clinically diagnosing Achilles tendinopathy

Test

Definition of test

Feature

Core health

domain

Subjective history

Self-reported

Clinician asks patient "Can you point out

location of pain

where you get your pain"

Pain located 2-6cm above the calcaneal insertion

\section{N/A}

(midportion)

Pain located in the distal $2 \mathrm{~cm}$ of the Achilles

tendon

Self-reported pain

with tendon loading

Patient reported intensity of pain using a VAS or NPRS while performing an Achilles tendon-specific loading task (single-leg heel raise, hopping)

Self-reported tendon stiffness or pain over a specified time

Clinician asks about pain and stiffness over specified timeframes (e.g. morning, night, 24 hours)

Self-reported overall rating of Achilles

Clinician asks "Can you rate your Achilles tendon where $100 \%$ represents no problems tendon and $0 \%$ is the worst-case scenario"

Pain reported increased pain on a VAS or NPRS with Achilles tendon-specific loading task (single-leg heel raise and hopping)

Patient reported morning stiffness or pain Patient reported pain or stiffness at the onset of activity that may "warm-up"

Patient reported level of condition

Pain with loading or activity

Pain over a specified time

Patient rating of overall condition

Patient reported pain located $2-6 \mathrm{~cm}$ above the Performed by the clinician gently palpating the whole length of the tendon in a proximal to distal direction

subjective opinion of tendon thickening or swelling

Patient reported pain located in the distal $2 \mathrm{~cm}$ of the Achilles tendon with or without subjective opinion of tendon thickening or swelling

Single-leg heel raise

Performed by patient rising up on to tip toes and lowering back down in a controlled

Clinician recorded number of completed single-

leg heel raises on each leg manner, on both the affected and non-affected leg

Hopping

Performed by participant hopping on the spot
Clinician recorded number of completed hops on each leg
Physical function

N/A

capacity

Physical function capacity 
The Royal London

Hospital Test

Performed by the clinician palpating the tendon for any local tenderness with the ankle either in neutral position or in slight plantarflexion. The ankle is then actively dorsiflexed and plantarflexed. With the ankle in maximum dorsiflexion, the portion of the tendon found to be tender is palpated again.

Painful Arc Sign

Performed by the clinician identifying the intratendinous swelling in the tendon and asking the patient to actively dorsiflex and plantarflex the ankle joint observing the movement of the swelling between the malleoli

\section{Outcome measures}

VISA-A

PCS

SF-12
The VISA-A questionnaire is a valid and reliable tool to evaluate clinical severity of Achilles tendinopathy that has been translated into multiple languages. Patients can selfadminister the questionnaire

Patients are asked to indicate the degree to which they have the above thoughts and feelings when they are experiencing pain using the 0 (not at all) to 4 (all the time) scale.

The SF-12 is a self-reported outcome measure assessing the impact of health on an individual's everyday life.
Patient reported pain on palpation reduces significantly or disappear with maximum dorsiflexion

The intratendinous swelling moves relative to the malleoli with the Achilles tendon during the ankle movement

The maximum score is 100 , with healthy subjects scoring a minimum of 96.177

A total score is yielded (ranging from 0-52), with a score of 30 or below indicating a clinically relevant level of catastrophising. ${ }^{178}$

The SF-12 creates two summary scores, mental health and physical health. ${ }^{179}$
N/A

$\mathrm{N} / \mathrm{A}$

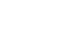

Disability

Psychological factors

Quality of Life

2 N/A, not applicable; cm, centimetres; VAS, Visual Analogue Scale; NPRS, Numerical Pain Rating Scale; VISA-A, Victorian Institute

3 of Sport Assessment-Achilles; PCS, Pain Catastrophising Scale; SF-12, 12-Item Short Form Survey 
Figure 1

\section{Overall study design}

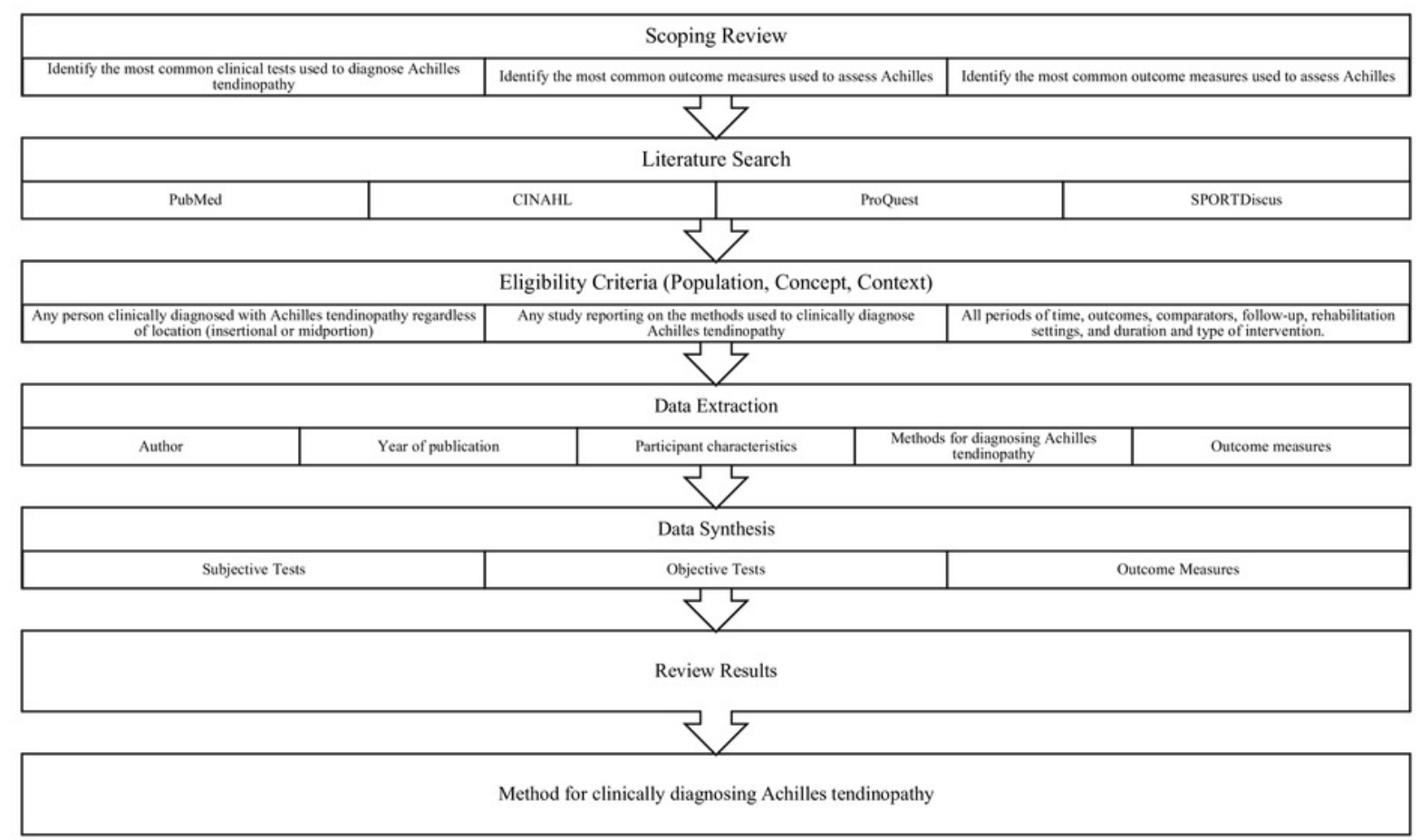

Figure 1: Overall study design 
Figure 2

Preferred Reporting Items for Systematic Reviews and Meta-analysis flow diagram 


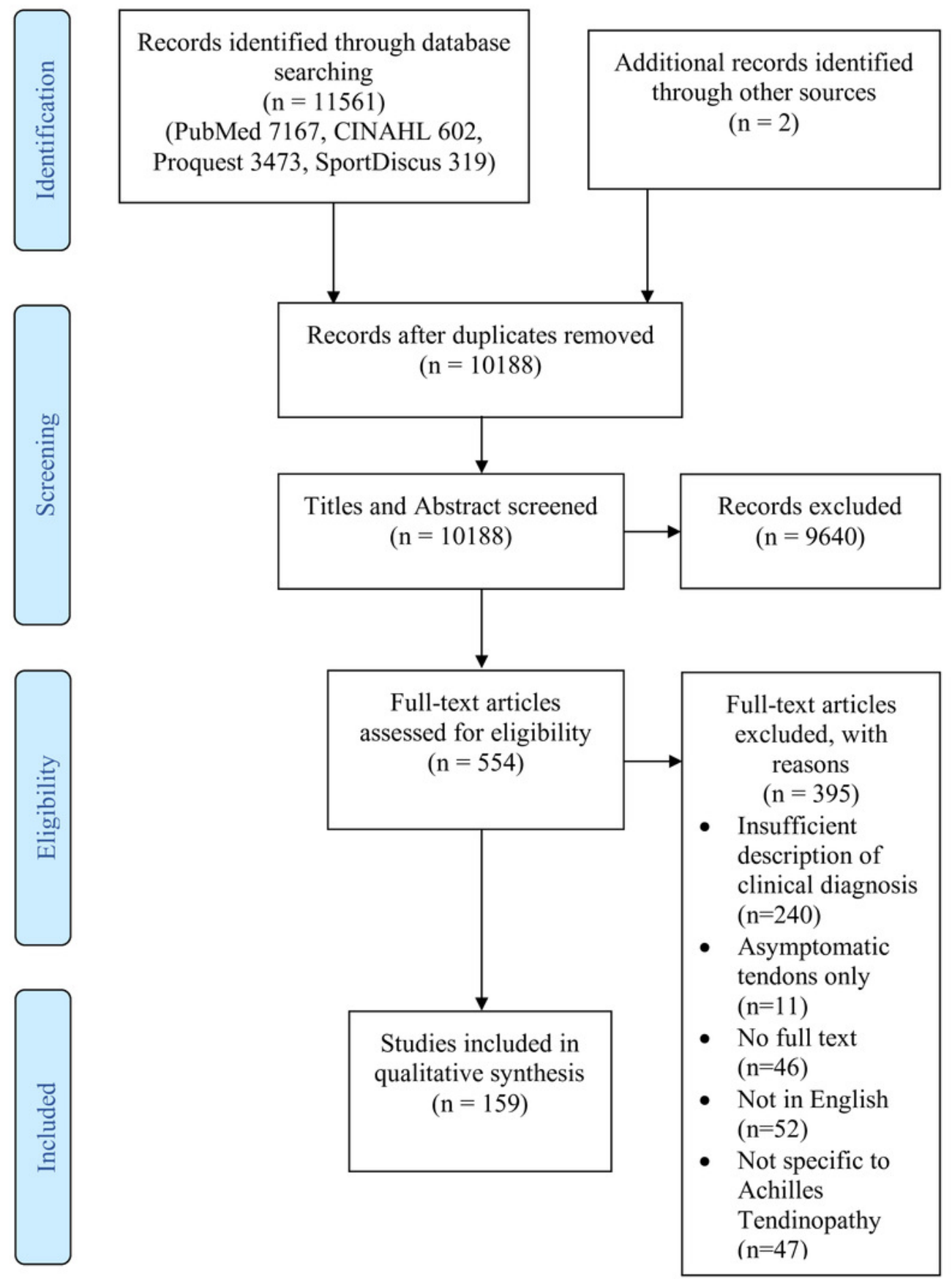

Figure 2: Preferred Reporting Items for Systematic Reviews and Meta-analysis flow diagram 
Figure 3

Terminology used to describe the clinical presentation of Achilles tendon pain and impaired function 


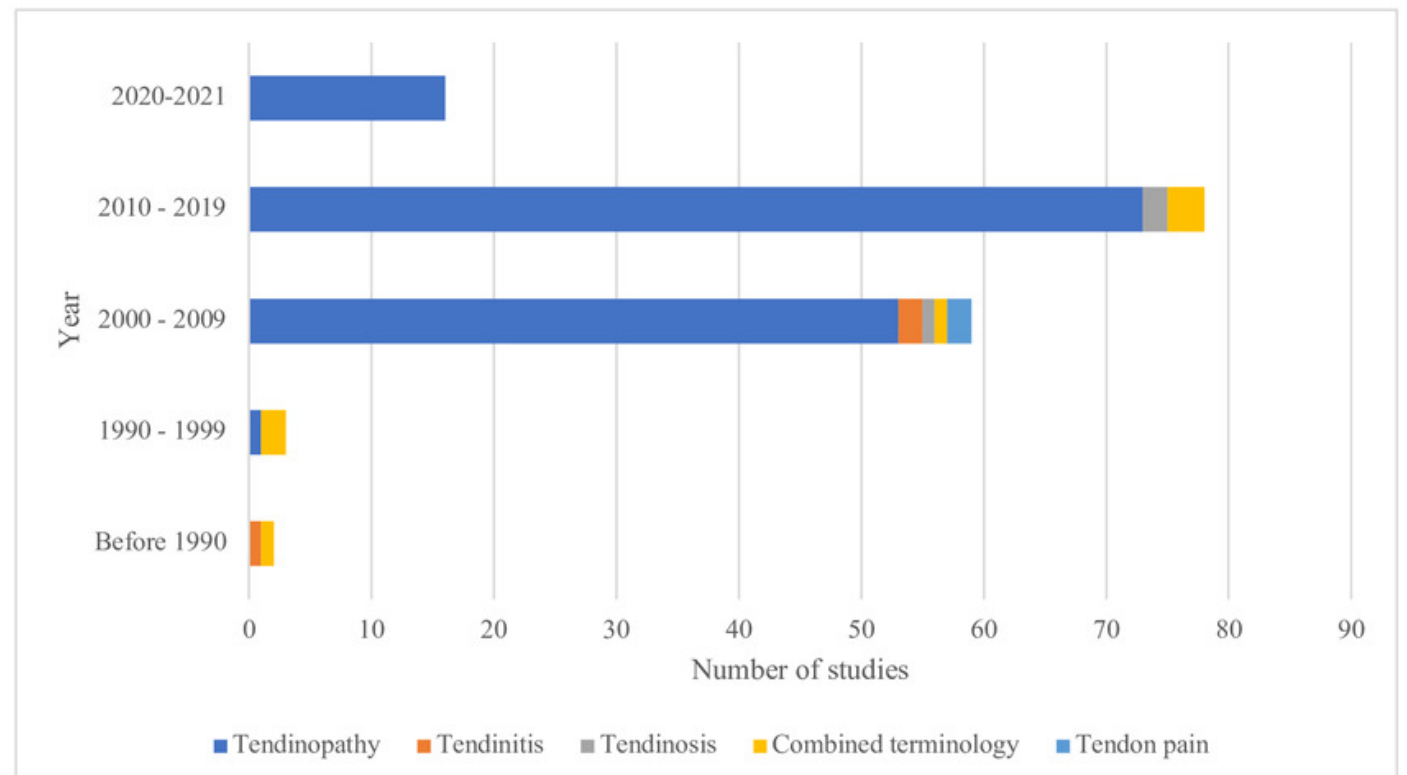

Figure 3: Terminology used to describe the clinical presentation of Achilles tendon pain and impaired function 
Figure 4

Outcome measures used to measure Achilles tendinopathy categorised by purpose. 


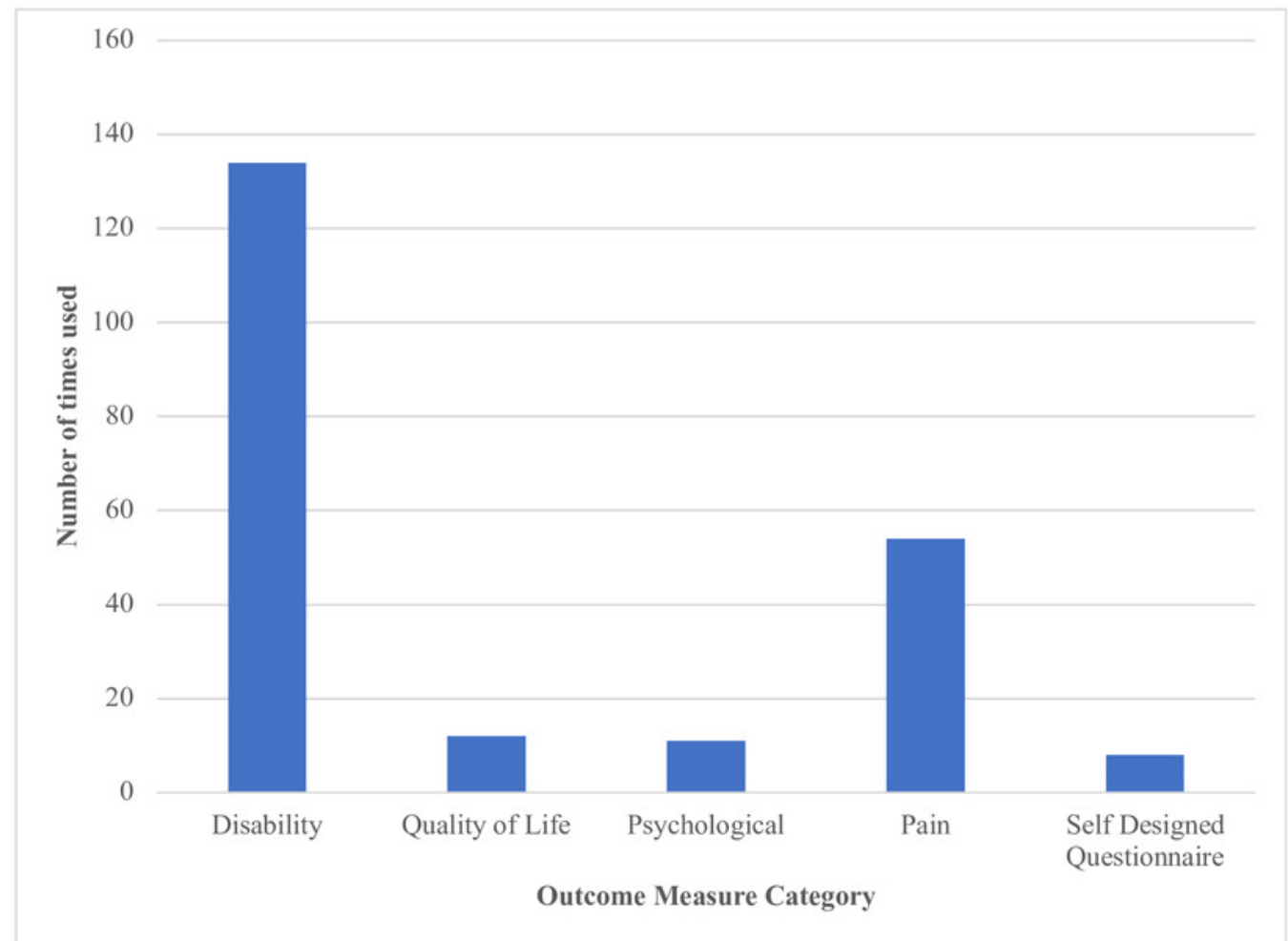

Figure 4: Outcome measures used to measure Achilles tendinopathy categorised by purpose. 